\title{
Pharmacogenomics and the Yin/Yang actions of ginseng: anti-tumor, angiomodulating and steroid-like activities of ginsenosides
}

\author{
Patrick Ying Kit Yue ${ }^{1}$, Nai Ki Mak², Yuen Kit Cheng2, Kar Wah Leung1, \\ Tzi Bun $\mathrm{Ng}^{3}$, David Tai Ping Fan ${ }^{4}$, Hin Wing Yeung ${ }^{5}$ and Ricky Ngok \\ Shun Wong*1
}

Address: ${ }^{1}$ Department of Biology, Faculty of Science, Hong Kong Baptist University, Kowloon Tong, Hong Kong SAR, China, ${ }^{2}$ Department of Chemistry, Faculty of Science, Hong Kong Baptist University, Kowloon Tong, Hong Kong SAR, China, ${ }^{3}$ Department of Biochemistry, Faculty of Medicine, Chinese University of Hong Kong, Hong Kong SAR, China, ${ }^{4}$ Angiogenesis \& TCM Laboratory, Department of Pharmacology, University of Cambridge, Tennis Court Road, CB2 1PD, UK and 5 International Society for Chinese Medicine, A \& C, 1st floor, Block 2, University of Macau, Av. Padre Tomas Pereira, Taipa, Macao SAR, China

Email: Patrick Ying Kit Yue - patrick@hkbu.edu.hk; Nai Ki Mak -nkmak@hkbu.edu.hk; Yuen Kit Cheng -ykcheng@hkbu.edu.hk; Kar Wah Leung - 03414604@hkbu.edu.hk; Tzi Bun Ng - b021770@mailserv.cuhk.edu.hk; David Tai Ping Fan - tpf1000@cam.ac.uk; Hin Wing Yeung - hwyeung@cmjournal.org; Ricky Ngok Shun Wong* - rnswong@hkbu.edu.hk

* Corresponding author

Published: I5 May 2007

Chinese Medicine 2007, 2:6 doi:10.1 I86/1749-8546-2-6
Received: 29 November 2006

Accepted: 15 May 2007

This article is available from: http://www.cmjournal.org/content/2///6

(c) 2007 Yue et al; licensee BioMed Central Ltd.

This is an Open Access article distributed under the terms of the Creative Commons Attribution License (http://creativecommons.org/licenses/by/2.0), which permits unrestricted use, distribution, and reproduction in any medium, provided the original work is properly cited.

\begin{abstract}
In Chinese medicine, ginseng (Panax ginseng C.A. Meyer) has long been used as a general tonic or an adaptogen to promote longevity and enhance bodily functions. It has also been claimed to be effective in combating stress, fatigue, oxidants, cancer and diabetes mellitus. Most of the pharmacological actions of ginseng are attributed to one type of its constituents, namely the ginsenosides. In this review, we focus on the recent advances in the study of ginsenosides on angiogenesis which is related to many pathological conditions including tumor progression and cardiovascular dysfunctions.
\end{abstract}

Angiogenesis in the human body is regulated by two sets of counteracting factors, angiogenic stimulators and inhibitors. The 'Yin and Yang' action of ginseng on angiomodulation was paralleled by the experimental data showing angiogenesis was indeed related to the compositional ratio between ginsenosides $R g_{1}$ and $R b_{1}$. $R g_{1}$ was later found to stimulate angiogenesis through augmenting the production of nitric oxide (NO) and vascular endothelial growth factor (VEGF). Mechanistic studies revealed that such responses were mediated through the PI3K $\rightarrow$ Akt pathway. By means of DNA microarray, a group of genes related to cell adhesion, migration and cytoskeleton were found to be up-regulated in endothelial cells. These gene products may interact in a hierarchical cascade pattern to modulate cell architectural dynamics which is concomitant to the observed phenomena in angiogenesis. By contrast, the anti-tumor and antiangiogenic effects of ginsenosides (e.g. $R g_{3}$ and $\mathrm{Rh}_{2}$ ) have been demonstrated in various models of tumor and endothelial cells, indicating that ginsenosides with opposing activities are present in ginseng. Ginsenosides and Panax ginseng extracts have been shown to exert protective effects on vascular dysfunctions, such as hypertension, atherosclerotic disorders and ischemic injury. Recent work has demonstrates the target molecules of ginsenosides to be a group of nuclear steroid hormone receptors. These lines of evidence support that the interaction between ginsenosides and various nuclear steroid hormone receptors may explain the diverse pharmacological activities of ginseng. These findings may also lead to development of more efficacious ginseng-derived therapeutics for angiogenesis-related diseases. 


\section{Panax ginseng Background}

Ginseng, Panax ginseng C.A. Meyer, a precious Chinese traditional medicinal herb, has been known clinically used in China for thousands of years. The genus name 'Panax' was derived from Greek. 'Pan' means 'all' and 'axos' means 'cure'. Literally 'Panax' can be translated as 'cure-all' or panacea. The herbal root is named ginseng because it is shaped like a man. Actually the term 'ginseng' represents two Chinese ideograms: 'gin' (pronounced ren) refers to 'man' and 'seng' (pronounced shen) refers to 'essence' It is believed to embody man's three mythical essences - body, mind and spirit. Thus it is also referred to as the lord or king of herbs [1]. Its medicinal efficacy was first documented in Shengnong Bencao Jing and it was later summarized by Li Shizhen in Bencao Gangmu and Zhongyao Zhi (Chinese Materia Medica) by People's Health Publishing House, Beijing, published in 1596 and 1959 respectively $[1,2]$. In the 18 th century, the effectiveness of ginseng was recognized in the West, and subsequently, a large number of investigations were conducted on its botany, chemistry, pharmacology and therapeutic applications [3-7]. Ginseng has been used as a general tonic or adaptogen for promoting longevity especially in the Far East, especially China, Korea and Japan [8]. Ginseng is now one of the most popular herbal medicines used nutraceutically with an annual sale of over USD 200 million.

Ginseng is a deciduous perennial plant that belongs to the Araliaceae family. Currently, twelve species have been identified in the genus Panax (Table 1) [9]. Among them, Panax ginseng C. A. Meyer (Araliaceae), cultivated in China, Korea, Japan, Russia, and the US, P. quinquefolium $\mathrm{L}$ (American ginseng), grown in southern Canada and the US and $P$. notoginseng, cultivated in Yunnan and Guangxi provinces in China, represent the three most extensively investigated species. The pharmacological and therapeutic effects of ginseng have been demonstrated to affect the central nervous system (CNS), cardiovascular system, endocrine secretion, immune function, metabolism, biomodulating action, anti-stress, and anti-aging [5]. Recently, there have been controversies concerning the usefulness of ginseng in cancer therapy. Most studies claimed that the pharmacological effects of ginseng are attributed to its bioactive constituents such as ginsenosides, saponins, phytosterols, peptides, polysaccharides, fatty acids, polyacetylenes, vitamins and minerals [10]. In this review, we focus on the recent advances in the studies of ginsenosides on the modulation of angiogenesis (i.e. formation of blood vessels) which is a common denominator of many diseases, such as tumor and cardiovascular disorders (e.g. atherosclerosis).

\section{Ginsenosides of ginseng}

The most prominent constituent of ginseng is a saponin glycoside known as ginsenosides (Rx) (Figure 1). Recent research indicates that most of the pharmacological effects of ginseng are attributed to ginsenosides [11]. In general, the contents of ginsenosides vary widely ranging from 2 to $20 \%$ depending on the species, age and part of ginseng, and even vary with the preservation or extraction method [11-13]. More than 30 ginsenosides have been isolated, and characterized from various Panax species [14,15]. In terms of their chemical structural characteristics, ginsenosides can be classified into three major categories, namely protopanaxadiols (PPD) (e.g. $\mathrm{Rb}_{1}, \mathrm{Rb}_{2}, \mathrm{Rc}, \mathrm{Rd}, \mathrm{Rg}_{3}, \mathrm{Rh}_{2}$ ), protopanaxatriols (PPT) (e.g. Re, Rf, $\operatorname{Rg}_{1}, \mathrm{Rg}_{2}, \mathrm{Rh}_{1}$ ) and the oleanolic acid derivatives. Ginsenosides have a steroid-like skeleton consisting of four trans-rings, with modifications from each other depending the type (e.g. glucose, maltose and fructose), number of sugar moieties and the sites of attachment of the hydroxyl group (e.g. C3, C-6, or C-20) (Figure 1). Ginsenosides are amphipathic in nature. The hydroxyl $(-\mathrm{OH})$ group of ginsenosides allows both interactions between the polar head of the membrane phospholipids and the $\beta$-OH group of cholesterol, while the hydrophobic steroid backbone can interact with the hydrophobic side chains of fatty acids and cholesterol. Indeed, these physiochemical interactions are greatly determined by the numbers and sites of polar hydroxyl groups on each ginsenoside. Moreover, ginsenosides have been shown to interact with numerous membrane proteins such as ion channels, transporters and receptors, which leads to a broad range of physiological activities [16].

\section{Angiogenesis}

The term 'angiogenesis', first used by Hertig in 1935, refers to the formation of new blood vessels in the placenta [17]. Angiogenesis is a complex multi-step process which comprises activation, chemotactic invasion and migration, morphological alteration, proliferation, and capillary tube formation of endothelial cells (ECs) from pre-existing blood vessels (Figure 2). In this process, ECs have been shown to express all the information necessary to construct a vascular network. Under normal physiological conditions, most vasculature is quiescent, with only $0.01 \%$ of the ECs undergoing active cell division; thus angiogenesis is a relatively rare event that specifically occurs for a short and defined time period [18,19]. In addition, it is also tightly controlled by a relative balance of two groups of counteracting factors, namely angiogenic stimulators and inhibitors [20] (Figure 3).

\section{Sprouting and intussuceptive (non-sprouting) modes of angiogenesis}

Sprouting angiogenesis consists of several consecutive steps with extensive interactions between soluble factors, 
Table I: Species of Ginseng belonging to the genus Panax.

\begin{tabular}{|c|c|c|}
\hline Scientific name & $\begin{array}{l}\text { Common name (English } \\
\text { name) }\end{array}$ & Geographical distribution \\
\hline Panax ginseng C.A. Meyer & $\begin{array}{l}\text { Asian ginseng } \\
\text { Orient Ginseng } \\
\text { Chinese Ginseng } \\
\text { Korean Ginseng } \\
\text { Red Ginseng } \\
\text { White Ginseng } \\
\text { Tartary Ginseng } \\
\text { Tartary Root } \\
\text { Kirin Ginseng }\end{array}$ & $\begin{array}{l}\text { Korea } \\
\text { Japan } \\
\text { China } \\
\text { Russia } \\
\text { Germany }\end{array}$ \\
\hline Panax japonicus C.A. Meyer & $\begin{array}{l}\text { Japanese Ginseng } \\
\text { ChiKu }\end{array}$ & $\begin{array}{l}\text { East, Middle-south, South and South Yunnan } \\
\text { Japan }\end{array}$ \\
\hline Panax bipinnatifidus Seem & $\begin{array}{l}\text { Feather-leaf bamboo ginseng } \\
\text { Feather-leaved bamboo ginseng }\end{array}$ & $\begin{array}{l}\text { Hubei, China } \\
\text { Nepal } \\
\text { Eastern Himalayas }\end{array}$ \\
\hline Panax notoginseng (Burkill) F.H. Chen & $\begin{array}{l}\text { Sanchi Ginseng } \\
\text { Tienchi Ginseng } \\
\text { Sanchu Ginseng } \\
\text { Notoginseng } \\
\text { San-qi ginseng } \\
\text { Tien-qi ginseng } \\
\text { Yunnan ginseng }\end{array}$ & $\begin{array}{l}\text { Yunnan, Guangxi } \\
\text { Guangdong, China }\end{array}$ \\
\hline Panax omeiensis J. Wen & Omei ginseng & $\begin{array}{l}\text { Sichuan, China } \\
\text { Nepal } \\
\text { Eastern Himalayas }\end{array}$ \\
\hline Panax pseudoginseng Wallich & Himalayan Ginseng & $\begin{array}{l}\text { South Tibet } \\
\text { Nepal } \\
\text { Eastern Himalayas }\end{array}$ \\
\hline Panax quinquefolius $\mathrm{L}$. & $\begin{array}{l}\text { American Ginseng } \\
\text { Occidental Ginseng } \\
\text { Canadian Ginseng }\end{array}$ & $\begin{array}{l}\text { Northeast, North, East China } \\
\text { Southern Canada } \\
\text { America (from Maine to Minnesota, south to Florida and west to } \\
\text { Oklahoma) }\end{array}$ \\
\hline Panax stipuleanatus H.T. Tsai and K.M. Feng & $\begin{array}{l}\text { Pingpien ginseng } \\
\text { Baisanqi } \\
\text { Tusangi } \\
\text { Yesangi } \\
\text { Zhujie qi }\end{array}$ & Southern Yunnan, China \\
\hline Panax trifolius L. & $\begin{array}{l}\text { Dwarf ginseng } \\
\text { Groundnut }\end{array}$ & $\begin{array}{l}\text { Ohio } \\
\text { Pennsylvania } \\
\text { Nova Scotia to Wisconsin and further south }\end{array}$ \\
\hline Panax wangianus S.C. Sun & Narrow-leaved pseudoginseng & Sichuan, China \\
\hline Panax vietnamensis $\mathrm{Ha}$ et Grushv. & $\begin{array}{l}\text { Bamboo ginseng } \\
\text { Vietnamese Ginseng }\end{array}$ & \\
\hline Panax zingiberensis C.Y. Wu and K.M. Feng & $\begin{array}{l}\text { Ginger ginseng } \\
\text { Ginger-like Pseudo-ginseng }\end{array}$ & Yunnan, China \\
\hline
\end{tabular}

[References: 5, 8, 9, MULTILINGUAL MULTISCRIPT PLANT NAME DATABASE-http://www.plantnames.unimelb.edu.au/Sorting/Panax.html\#bipinnatifidus and Ginseng: A Concise Handbook. Edited by James A, Duke. Reference Publications, Inc. 1989. Michigan, USA]

extracellular matrix (ECM) and cells. As shown in Figure 2 , during the early stage of angiogenesis, angiogenic factors such as vascular endothelial growth factor (VEGF) and fibroblast growth factor (FGF) emanate from conditioned cells (e.g. stromal cells, endothelial cells, blood) or surrounding tissues (e.g. ECM) to stimulate ECs [19]. These activated ECs secrete various types of enzymes including matrix metalloproteinases (MMPs), plasminogen activators (PA), gelatinase, collagenases and urokinases which bring about the degradation of basement membrane and ECM surrounding the parental blood vessels. Subsequently, the ECs migrate towards the angiogenic factors with the help of surface adhesion molecules or integrin receptors such as intercellular adhesion molecule-1 (ICAM-1), vascular cell adhesion molecule-1 (VCAM-1) and integrins $\alpha_{\mathrm{v}} \beta_{3}[21,22]$. Upon the induction of various angiogenic factors, ECs proliferate and align in a bipolar mode to form capillary sprouts. Finally, these ECs form a lumen and a capillary loop through which the blood can flow.
Intussusceptive microvascular growth, a novel mechanism of blood vessel formation and remodeling, occurs by internal division of the pre-existing capillary plexus without sprouting. It is initiated by protrusion of opposing capillary walls into the lumen where a contact is created between the ECs. Then the endothelial bilayer is perforated and numerous transcapillary tissue pillars with an interstitial core are formed. An extensive vascular tree is formed from the subsequent intussusceptive pillar formation and pillar fusions [23-25].

\section{Molecular regulation of angiogenesis}

Among the angiogenic regulators, VEGF and nitric oxide (NO) are the critical angiogenic stimulators. We have demonstrated that they are closely related to ginsenosidemediated angiomodulation. Both VEGF and NO play a critical role in the regulation of physiological angiogenesis including embryogenesis, reproduction and wound healing. They have also been implicated in pathological angiogenesis associated with tumors or many cardiovas- 


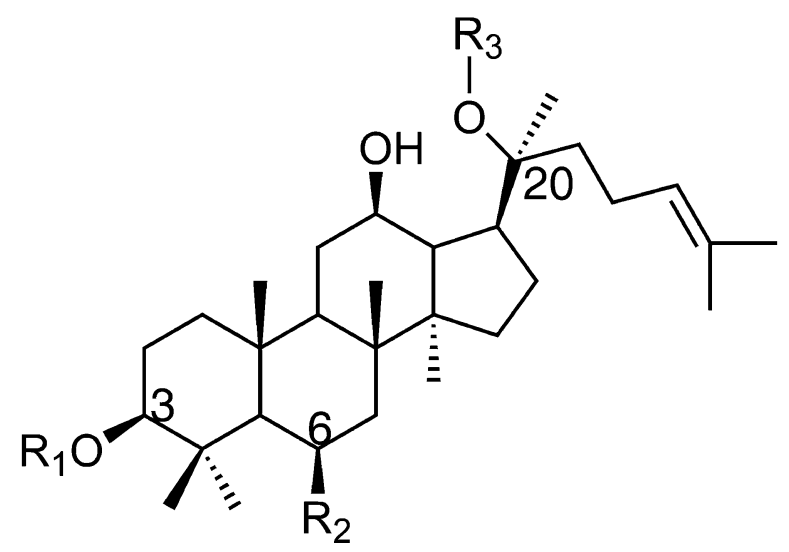

\begin{tabular}{llll}
\hline Ginsenoside & $\mathbf{R}_{\mathbf{1}}$ & $\mathbf{R}_{\mathbf{2}}$ & $\mathbf{R}_{\mathbf{3}}$ \\
\hline Protopanaxatriol & & & \\
$\mathbf{R g}_{\mathbf{1}}$ & $\mathrm{H}$ & $-\mathrm{O}-g l c$ & glc \\
$\mathbf{R g}_{2}$ & $\mathrm{H}$ & $-\mathrm{O}-g l c(2-1) r h a$ & $\mathrm{H}$ \\
$\mathbf{R e}$ & $\mathrm{H}$ & $-\mathrm{O}-g l c(2-1) r h a$ & glc \\
$\mathbf{R f}$ & $\mathrm{H}$ & $-\mathrm{O}-g l c(2-1) g l c$ & $\mathrm{H}$ \\
$\mathbf{R h}$ & $\mathrm{H}$ & $-\mathrm{O}-g l c$ & $\mathrm{H}$ \\
$\mathbf{F 1}$ & $\mathrm{H}$ & $-\mathrm{OH}$ & glc
\end{tabular}

Protopanaxadiol

\begin{tabular}{llll}
$\mathbf{R b}_{1}$ & $g l c(2-1) g l c$ & $\mathrm{H}$ & $g l c(6-1) g l c$ \\
$\mathbf{R b}_{2}$ & $g l c(2-1) g l c$ & $\mathrm{H}$ & $g l c(6-1) \operatorname{ara}(\mathrm{p})$ \\
$\mathbf{R g}_{3}$ & $g l c(2-1) g l c$ & $\mathrm{H}$ & $\mathrm{H}$ \\
$\mathbf{R h}_{2}$ & $g l c$ & $\mathrm{H}$ & $\mathrm{H}$ \\
$\mathbf{R c}$ & $g l c(2-1) g l c$ & $\mathrm{H}$ & $g l c(6-1) \operatorname{ara}(\mathrm{f})$ \\
$\mathbf{R d}$ & $g l c(2-1) g l c$ & $\mathrm{H}$ & $g l c$ \\
$\mathbf{R a}$ & $g l c(2-1) g l c$ & $\mathrm{H}$ & $g l c(6-1) g l c$ \\
$\mathbf{F 2}$ & $g l c$ & $\mathrm{H}$ & glc \\
Compound Y & $\mathrm{H}$ & $\mathrm{H}$ & $g l c(6-1) \operatorname{ara}(\mathrm{p})$ \\
Compound K & $H$ & $\mathrm{H}$ & $g l c$ \\
Compound $\mathbf{O}$ & $g l c$ & $\mathrm{H}$ & $g l c(6-1) \operatorname{ara}(\mathrm{p})$ \\
Compound Mc & $g l c$ & $\mathrm{H}$ & $g l c(6-1) \operatorname{ara}(\mathrm{f})$ \\
\hline
\end{tabular}

Figure I

The chemical structure of ginsenosides [6]. glc = glucosyl $\left(\mathrm{C}_{6} \mathrm{H}_{1 \mid} \mathrm{O}_{6}{ }^{-}\right)$; rha = rhamnosyl $\left(\mathrm{C}_{6} \mathrm{H}_{1 \mid} \mathrm{O}_{5}^{-}\right)$; ara $=$arabinosyl $\left(\mathrm{C}_{5} \mathrm{H}_{9} \mathrm{O}_{5}{ }^{-}\right) ; \mathrm{p}=$ pyran; $\mathrm{f}=$ furan. 
(A)
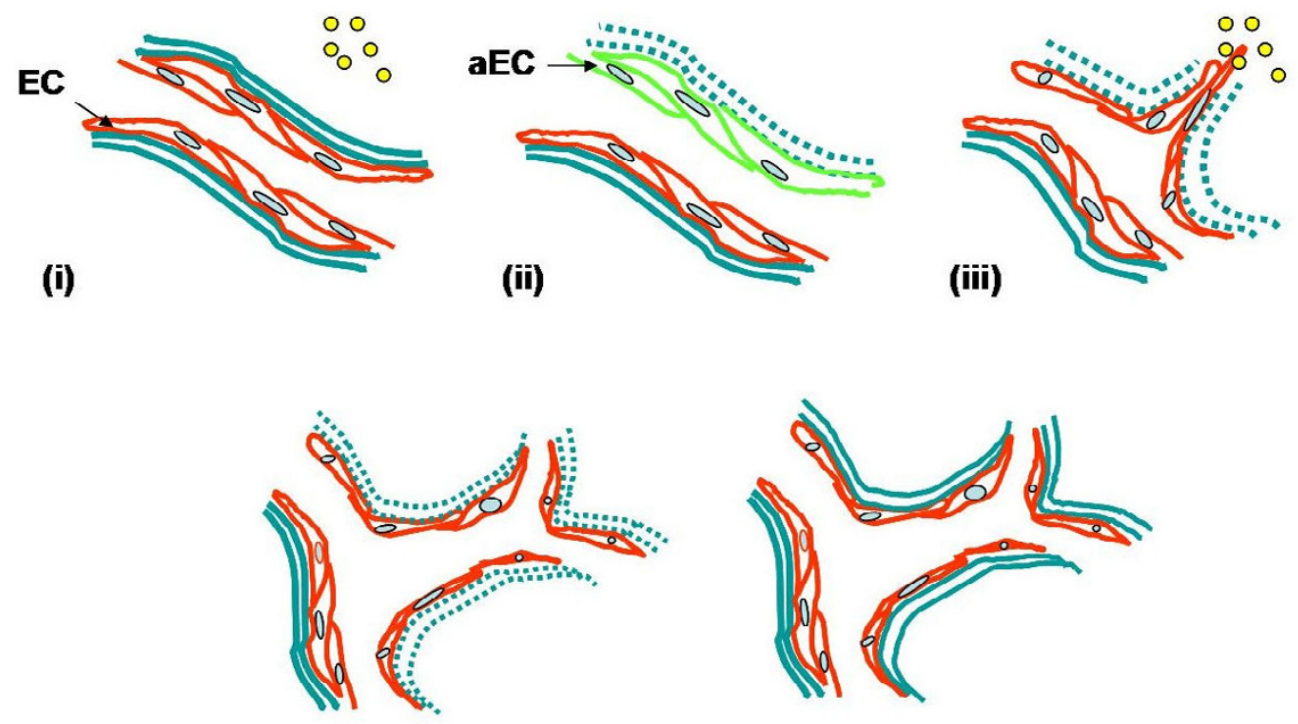

(iv)

(v)

(B)

(i)

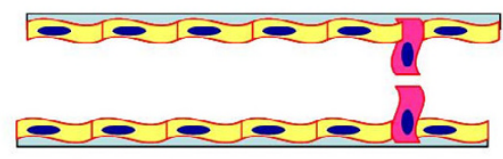

(ii)

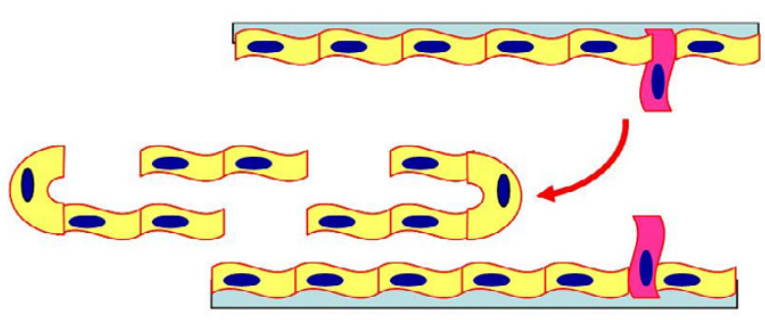

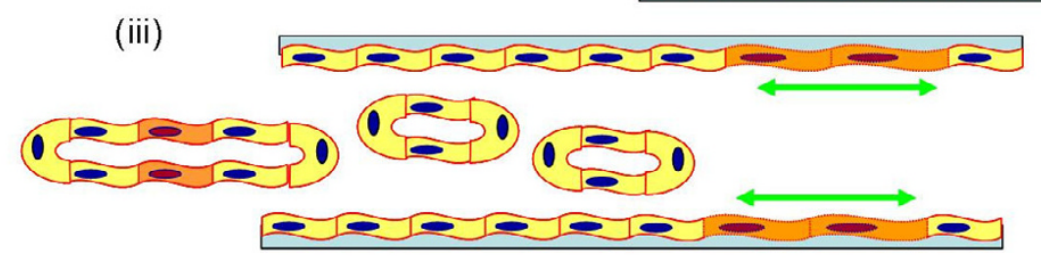

Figure 2

The process of angiogenesis. A) Sprouting angiogenesis: formation of blood vessels is a multi-step process, which includes (i) reception of angiogenic signals (yellow spot) from the surrounding by endothelial cells (EC); (ii) retraction of pericytes from the abluminal surface of capillary and secretion of protease from activated endothelial cells (aEC) and proteolytic degradation of extracellular membrane (green dash-line); (iii) chemotactic migration of EC under the induction of angiogenic stimulators; (iv) proliferation of EC and formation of lumen/canalisation by fusion of formed vessels with formation of tight junctions; (v) recruitment of pericytes and deposition of new basement membrane and initiation of blood flow. B) Non-sprouting angiogenesis - intussusceptive microvascular growth: it is initiated by (i) protrusion of opposing capillary walls towards the lumen; (ii) perforation of the EC bilayer and formation of many transcapillaries with interstitial core (red arrow); (iii) formation of the vascular tree from intussusceptive pillar formation and pillar fusion and elongation of capillaries (green arrows). 


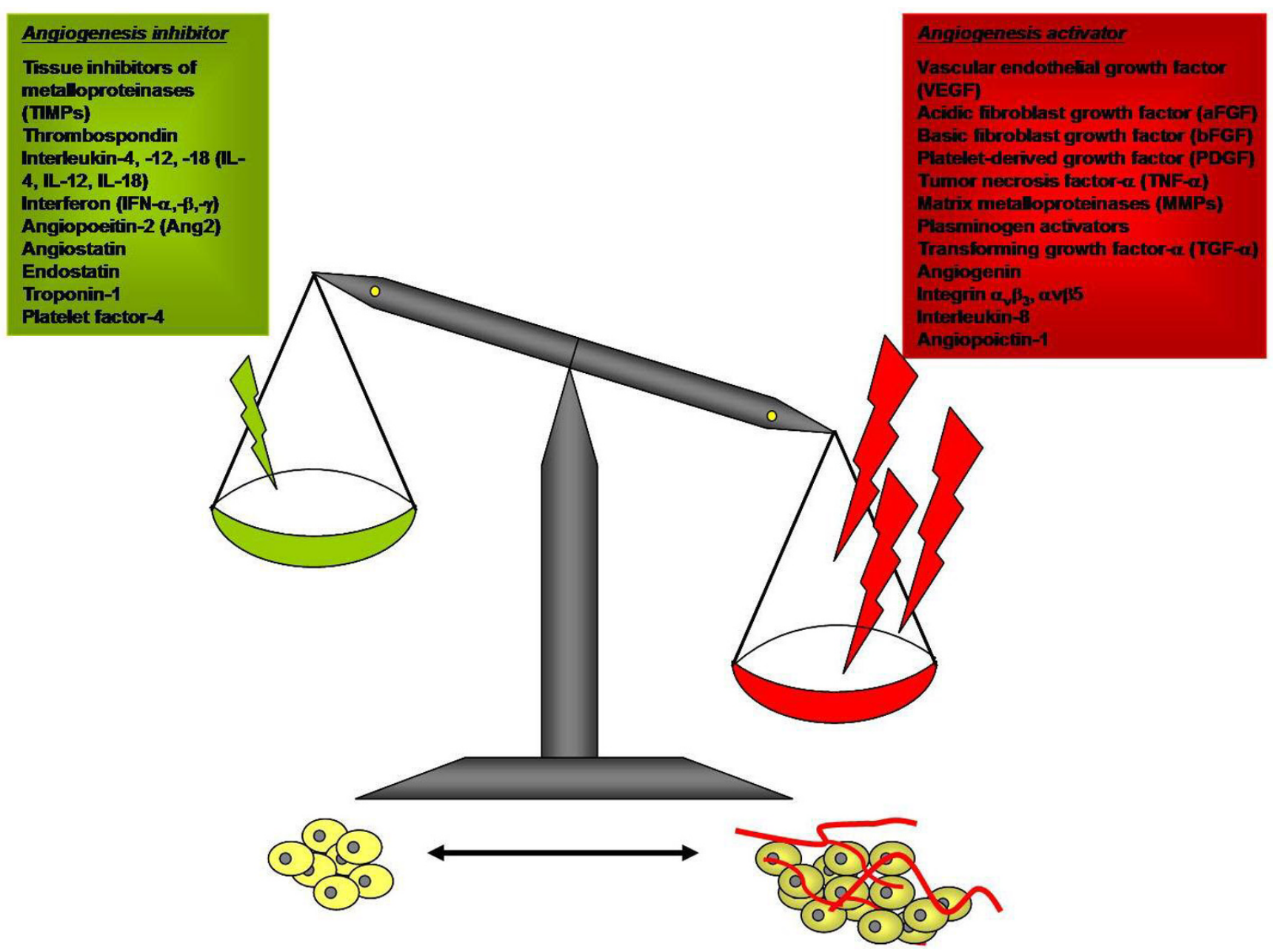

Figure 3

The balance hypothesis of the 'angiogenic switch'. Angiogenesis is tightly controlled by the balance of two sets of counteracting factors - angiogenic activators and inhibitors. The stability of 'angiogenic switch' determines the time of initiation of the subsequent angiogenic process. When there are more angiogenic stimulators than angiogenic inhibitors, as in the case of solid tumors, normal wound healing or female endometrial repair, the 'angiogenic switch' will be turned on and angiogenesis will proceed. Furthermore, during the process, each step is strictly mediated by the balance of different types of angiogenic stimulators or inhibitors. In some pathological cases, the 'angiogenic switch' remains in the 'ON' mode which leads to 'nonstop' formation of new blood vessels and ultimately many physiological disorders and diseases.

cular disorders (such as atherosclerosis or ischemic injury). VEGF, which belongs to the VEGF family, is expressed in different tissues including the brain, liver, spleen and many cell types [26]. In vitro, VEGF not only acts as a survival factor and mitogen for ECs, but also induces the expression of many angiogenesis-related factors, including ICAM-1, VCAM-1, uPA, PAI-1, UPAR and MMPs. All these gene products are related to the increase of ECM degradation, migration and tube formation of ECs, whereas their effects on intussusception remain to be investigated [27-30]. The critical roles played by VEGF in embryonic vasculogenesis and angiogenesis have been demonstrated [31,32]. Inactivation of a single VEGF allele in mice resulted in embryonic lethality between days 11 and 12. The growth of VEGF+/- embryos was retarded and there were many developmental anomalies.

Endothelium-derived NO has been implicated in mediating a multiplicity of processes involved in angiogenesis. In fact, there are many angiogenic factors, such as VEGF, transforming growth factor $\beta$ (TGF- $\beta$ ) and fibroblast growth factor (FGF), which can up-regulate the expression of endothelial NO synthase (eNOS), thereby inducing the release of NO [33-36]. VEGF- or bFGF-activated human umbilical vein endothelial cells (HUVEC) have been found to secrete NO on Matrigel substratum and subse- 
quently form a tube-like structure, whereas such tube formating action is abolished by eNOS antagonist, $\mathrm{N}^{\omega}$-nitroL-arginine methylester (L-NAME) [37-39]. On the one hand, NO increases EC proliferation by acting as a survival factor and enhances migration by augmenting the expression of $\alpha_{v} \beta_{3}$ and matrix-ECs interaction through the up-regulation of uPA [40-44]. Moreover, its vasodilating activity is the most prominent effect shown in the modulation of cardiovascular physiology [45]. On the other hand, disruption of the eNOS pathway can result in an impairment of normal angiogenesis, enhancement of tumor pathogenesis, and cardiovascular disorders [4649].

VEGF and NO are working closely with each other in the modulation of angiogenesis, whereas NO is both an upstream and a downstream mediator or an effector of VEGF-dependent angiogenesis. Upon binding to its receptors, VEGF initiates complicated signaling cascades resulting in NO production and subsequent activation of ECs and smooth muscle cells in vessels, keratinocytes and macrophages in wounds, and tumor cells. Furthermore, through the activation of the PI3K/Akt pathway, NO can increase VEGF synthesis in a positive feedback manner $[46,50-54]$.

\section{Angiogenesis in health and diseases Normal physiology}

In health, angiogenesis is under stringent control by an 'angiogenic switch' (Figure 3), and rarely occurs in adults except for embryogenesis, placentation, endometrial repair and wound healing $[20,55]$. In the latter case, formation of neovessels is necessary to sustain newly formed granulation tissues, in such a way that the ECs divide with a turnover rate of about 5 days, giving rise to a new microvascular network. During the menstrual cycle, however, angiogenesis occurs in corpora lutea and endometrium with rapid growth and regression [56-59]. Thus angiogenesis is normally in the quiescent state but is capable of both rapid activation and shutting down.

\section{Pathophysiology}

Excessive angiogenesis has been defined as a prominent pathological feature of many diseases such as tumor, rheumatoid arthritis, atherosclerosis, psoriasis and diabetic retinopathy [60-63] (Table 2). During the early stage of tumorigenesis, tumors are usually not angiogenic (Figure 4). Since oxygen can only diffuse to around 150-200 microns from capillaries, solid tumors can only grow to 1-2 $\mathrm{mm}^{3}$ autonomously at which stage they may exist for months or years without neovascularization (i.e. avascular phase). However, once tumor cells switch to the angiogenic phenotype (i.e. vascular phase), an extensive vascular network is constructed through sprouting or nonsprouting angiogenic mechanisms. The large amounts of angiogenic factors, mainly VEGF secreted by tumor cells or activated ECs, form a positive feedback on angiogenesis, leading to tumor growth and subsequent metastasis. $[64,65]$. A similar case has also been found in atherosclerosis, in which excessive angiogenesis enhances plaque growth in such a way to sustain perfusion, increase leukocyte exchange, deposition of proatherogenic plasma molecules and finally promote intraplague hemorrhage [66].

An insufficient amount of angiogenic stimulators and/or an excess of angiogenic inhibitors can tip the balance resulting in inadequate or limited angiogenesis. Inadequate angiogenesis can also cause serious pathological outcomes such as stroke, Alzheimer disease, chronic wound, ulceration, ischemic coronary artery, critical limb ischemia, hypertension and hair loss [62,63]. In diseases such as ischemic coronary artery or limb ischemia, the functional blood flow is partially lost in certain organs or limbs. Poor blood circulation greatly prolongs the recovery period or even results in morbidity or death. A similar phenomenon has been found in the aberrant wound repair in diabetic and gastric ulcer $[67,68]$.

\section{Angiotherapy: angiogenesis as a therapeutic target}

Since the discovery in the early 1970 s that tumor progression is angiogenesis-dependent, the concept of 'angiotherapy' has been hypothesized as a therapeutic strategy [69]. Ideally, this strategy could be used in the case of insufficient angiogenesis (e.g. heart ischemia) through the stimulation of neovessel formation by introducing angiogenic stimulators. An over-burst of uncontrolled angiogenesis (e.g. tumors) could be treated using angiogenic inhibitors to shut down the formation of neovessels [70-72] (Table 2 ). After thirty years, this idea became a reality when the first-generation anti-angiogenic drugs called Avastin (bevacizumab) and Macugen (pegaptanib sodium) were approved by the Food and Drug Administration in the US in 2004 and 2005 respectively for clinical application in cancer patients [73].

In fact, a large number of anti-angiogenic agents (e.g. thalidomide, TNP-470, endostatin, and angiostatin) are being tested or undergoing preclinical or clinical trials either alone or in combination with conventional therapies [74-76]. Most of these drugs target the ECs rather than tumor cells, thereby affecting different stages of angiogenesis. Therefore, they are less likely to cause bone marrow suppression, gastrointestinal symptoms or hair loss than conventional tumor therapies.

\section{Pharmacological actions of ginsenosides Anti-tumor effects of ginsenosides}

In Asia, ginseng has been used as a medicinal herb for a long time to treat various ailments such as malignant dis- 
Table 2: Angiogenic diseases

\begin{tabular}{ll}
\hline Diseases/disorders & Organ/organ system \\
\hline $\begin{array}{l}\text { Atherosclerosis } \\
\text { hypertension }\end{array}$ & Cardiovascular system \\
Vascular dementia & \\
Haemangioma & \\
Haemangioendothelioma & Ocular \\
Ischemic heart, limb & \\
Diabetic retinopathy & \\
Ischemic retinopathy & \\
Neovascular glaucoma & Skin \\
Cancer & \\
Warts & \\
Kaposi's sarcoma & \\
Neoplasms & \\
Psoriasis & Reproductive system \\
Ulcer & \\
Dysfunctional uterine bleeding & \\
Endometriosis & \\
Neoplasms & \\
Placental insufficiency & \\
Cancer & Bones, joints \\
Rheumatoid arthritis & Digestive system \\
Ulcer & \\
Cancer & \\
Crohn's disease & \\
\hline
\end{tabular}

eases. Experimental studies from the past two decades have shown that both the anti-tumor activities and therapeutic effects of ginseng are mainly attributed to ginsenosides which induce cell death and inhibit metastasis.

\section{Induction of cell death}

Several patterns of eukaryotic cell death, namely apoptosis, autophagy, paraptosis, mitotic catastrophe and necrosis, have been recognized [77-79]. The process of cell death can be either caspase-dependent or caspase-independent. It is also known that mitochondria play an important role in the initiation of apoptosis. Different ginsenosides induce apoptosis through various signaling cascades. $\mathrm{Rh}_{2}$ and compound $\mathrm{K}$ (the metabolites of $\mathrm{Rb}_{1}$ ) have been shown to induce apoptosis in prostate cancer cells, ovarian cancer cells, neuroblastoma cells and A549 lung adenocarcinoma cells by activating caspase- 3 and - 8 [80-83]. Kim et al. further demonstrated that such apoptotic activation can be $\mathrm{Bcl}-2, \mathrm{Bcl}-\mathrm{xL}$ or Bax independent [84-87]. In human neuroblastoma (SK-N-BE) and rat glioma models, $\mathrm{Rh}_{2}$-induced apoptotic cell death has been implicated via protein kinase $\mathrm{C}$ (PKC) and reactive oxygen-dependent mechanisms [88-90]. The apoptotsis inducing activities of other ginsenosides such $\mathrm{as}_{\mathrm{Rb}}, \mathrm{Rc}$, $\mathrm{Rg}_{3}, \quad \mathrm{RS}_{4}$ and IH901 (20-O-(beta-D-glucopyranosyl)20(S)-protopanaxadiol, an intestinal bacterial metabolite of ginseng formed from $\mathrm{Rb}_{1}, \mathrm{Rb}_{2}$ and $\mathrm{Rc}$, have also been observed in different human tumor cell lines [87-89]. These findings suggest that induction of tumor cell apop- tosis by ginsenosides may be one of the mechanisms in the elimination of tumor cells.

\section{Anti-proliferation}

Inhibition of cell cycle progression has also been implicated as a chemopreventive mechanism of ginsenosides. $\mathrm{Rh}_{2}, \mathrm{Rg}_{3}$, IH901 and PD have been shown to arrest the growth of human tumor cell lines such as A549 lung tumor cells, LNCaP and PC3 prostate carcinoma cells, U937 leukemia cells, SK-HEP-1 hepatoma cells and HeLa cells $[80-83,91]$. Mechanistically, $\mathrm{Rh}_{2}$ has been shown to arrest the cell cycle at the G1/G0 phase, and to prolong the S-phase in intestinal (Int-407 and Caco-2) cells and SKHEP-1 hepatoma cells [92-94]. It also induces cell arrest by down-regulation of cyclin/Cdk complex kinase activity, inhibition of E2F release in MCF-7 breast carcinoma cells, or by modulation of three modules of MAP kinases in prostate carcinoma cells $[81,95]$.

Active growth of tumor cells can also be attenuated by induction of terminal differentiation and this approach has been developed as one of the strategies in cancer treatment [96]. Previously, Zeng and Tu showed that $\mathrm{Rh}_{2}$ treated hepatocarcinoma (SMMC-7721) cells exhibited the morphological characteristics of mature cells. Results showed that $\mathrm{Rh}_{2}$ can reduce telomerase activity which affects transcriptional activity in cells and facilitates both cell differentiation and cell arrest $[97,98]$. Moreover, $\mathrm{Rh}_{2^{-}}$ induced cell differentiation has also been found in B16 melanoma cells and F9 teratocarcinoma cells $[99,100]$. 


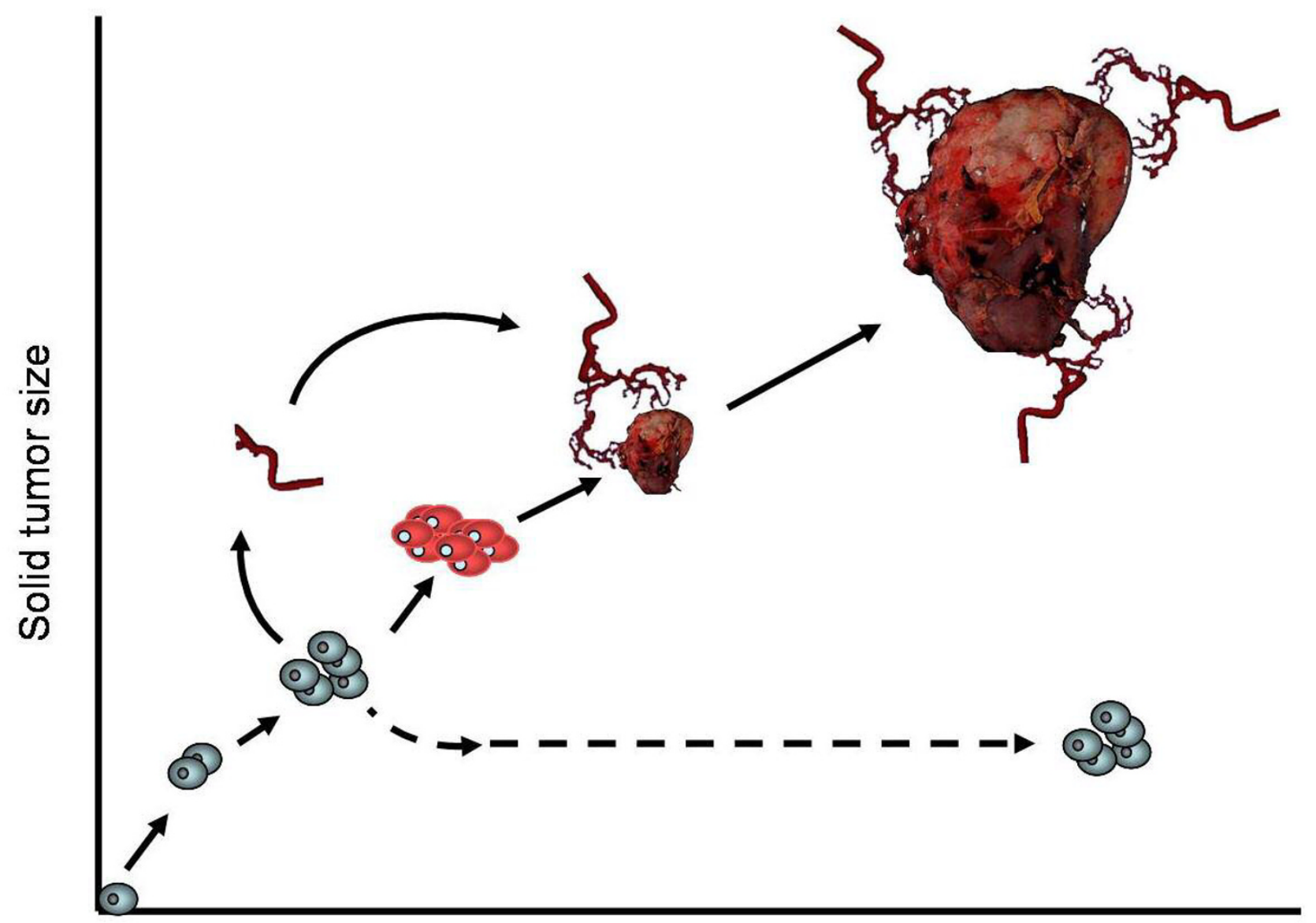

\section{Avascular phase}

\section{Proliferation = apoptosis}

\section{Exponential growth}

\section{Figure 4}

A fundamental step in tumorigenesis - angiogenesis. Angiogenesis is a critical step in the pathogenesis of solid tumors. Tumors remain in a dormant state (avascular phase) for a long time (up to several years), in which tumors keep their size within I $-2 \mathrm{~mm}^{3}$. When tumor progression starts, tumor cells secrete a large amount of angiogenic factors, mainly VEGF, to the surrounding tissues and blood capillaries. Once tumor angiogenesis is initiated, tumors enter a 'vascular phase' and become more aggressive. These newly formed blood vessels provide tumor cells with oxygen and nutrients for them to grow and for the initiation of metastasis.

After $\mathrm{Rh}_{2}$ treatment, B16 cells resembled epithelioid cells morphologically and the cells were arrested at the G1 phase. In vitro induction of differentiation of F9 cells was shown to involve the glucocorticoid receptor (GR). In the presence of a glucocorticoid antagonist (RU486), $\mathrm{Rh}_{1}$ - or $\mathrm{Rh}_{2}$-treated $\mathrm{F} 9$ cells did not differentiate into endodermlike cells. These hypotheses were further corroborated in the gel mobility shift assay, in which the glucocorticoid responsive element (GRE) was specifically detected, mainly in the nuclear extract of ginsenoside-treated F9 cells. Concomitantly the results were also recorded in the luciferase-reported gene assay.

\section{Anti-invasion and metastasis}

Cancer metastasis is a complex process involving angiogenesis and cell-cell interactions. Enzymes such as matrix 
metalloproteinases are known to play an important role in tumor invasion, metastasis as well as initiation of angiogenesis. Fujimoto et al. recently demonstrated that the invasiveness of the endometrial cancer cell lines HHUA and HEC-1-A was inhibited by treating the cells with ginsenoside $\mathrm{Rb}_{2}$ [101]. The inhibitory effect is due to suppression of MMP-2 expression. The association between down-regulation of MMP expression and reduction of invasiveness was also demonstrated in a highly metastatic HT1080 human fibroblast cell line. Purified ginseng components, PD and PT, down-regulated the expression of MMP-9 in HT1080 cells [102]. By contrast, the expression of MMP-2 was not affected by PD and PT. Whether the observed differential inhibition of MMP-2 and MMP-9 expression in these two groups of cells is cell type- or ginsenoside-dependent remains to be elucidated.

In addition, the anti-invasive effects of $\mathrm{Rb}_{2}, 20(\mathrm{~S})$ - and $20(\mathrm{R})-\mathrm{Rg}_{3}$ have been further demonstrated by Shinkai et al. [103] and Mochizuki et al. [104]. $\mathrm{Rg}_{3}$ was found to significantly inhibit in vitro invasion of rat ascites hepatoma cells (MM1), B16FE7 melanoma cells, human lung carcinoma (OC10) and pancreatic adenocarcinoma (PSN-1) cells. Intravenous $(10 \mu \mathrm{g} / \mathrm{mouse})$ or oral (100-1000 $\mu \mathrm{g} /$ animal) administration of both $\mathrm{Rg}_{3}$ and $\mathrm{Rb}_{1}$ inhibited lung metastasis of B16-BL6 melanoma and colon 26M3.1 carcinoma in mice [103-105]. Furthermore, $\mathrm{Rg}_{3}$ greatly reduced the volume or weight of tumors in xenotransplanted (e.g. Lewis lung carcinoma, human breast infiltrating duct carcinoma, human gastric tumor and B16-BL6 melanoma) or chemical-induced (e.g. hepatocellular carcinoma) tumor models [106-109].

\section{Effects of ginsenosides on multi-drug resistance}

The development of multi-drug resistance (MDR) is a major problem in cancer chemotherapy. Agents that can enhance the accumulation of chemotherapeutic drugs in tumor cells by targeting the MDR proteins is a novel approach to overcome this problem [110-112]. In an acute myelogenous leukemia cell model, PPT ginsenosides were found to exert a chemosensitizing effect on Pglycoprotein (Pgp)-mediated MDR leukemia cells by increasing intracellular accumulation of daunorubicin and doxorubicin [113]. The effect on the reversal of drug resistance was due to competitive binding of ginsenosides such as $\mathrm{Rg}_{3}$ with Pgp, thereby blocking drug efflux [114]. In other MDR leukemia cells such as daunomycin or vinblastine-resistant leukemia cell models, various ginsenosides including 20(S)-PPT, $\mathrm{Rh}_{2}$ and compound $\mathrm{K}$ were found to greatly enhance the cytotoxicity of anti-cancer drugs in a range of 2- to 46-fold through the blockage of drug efflux [115]. Moreover, other ginsenosides including Rc and Rd reduced the efflux pump activity in lymphoma cells [116]. Recently, we also demonstrated that ginsenosides could exert the chemosensitizing effect through direct interaction with breast cancer resistance protein (BCRP), but not Pgp in MCF-7 cells. Among the tested ginsenosides, $\mathrm{Rh}_{2}, \mathrm{PPD}$ and PPT have been found to increase the cytotoxicity of mitoxantrone $(\mathrm{MX})$, a potent anti-tumor drug, to human breast carcinoma MCF/MX cells which overexpress BCRP. The potency order of ginsenosides to inhibit BCRP is PPD $>\mathrm{Rh}_{2}>\mathrm{PPT}$. Neither $\mathrm{Rg}_{1}$ nor $\mathrm{Rh}_{1}$ was observed to inhibit BCRP or Pgp, whereas $\mathrm{Rg}_{3}$ was shown to be mild inhibitors. Previously, the C-6 substitution was hypothesized to confer anti-tumor activity. These findings suggest that the C- 6 substitution is also important to the BCRP-inhibitory activity of ginsenosides. In addition, the two glucose substitutions at $\mathrm{C}-3$ position such as $\mathrm{Rg}_{3}$ nearly abrogate its effect to inhibit BCRP. Our findings indicated that the inhibition of $M X$ efflux as mediated by BCRP and the enhanced uptake of MX is correlated to the attachment of the hydroxyl group and sugar substitution at different positions of the steroidal skeleton of ginsenosides [117].

\section{A new class of anti-tumor drugs: ginsenosides $R g_{3}$ and $R h_{2}$}

Both $\mathrm{Rg}_{3}$ and its metabolite form $\mathrm{Rh}_{2}$ have emerged in Mainland China and Taiwan as anti-cancer drugs in the form of capsules (e.g. 'Rg3 Shenyi Jiaonang' and 'GOOD LIFE ginsenoside Rh2 capsule'). Rg3 Shenyi Jiaonang suppresses tumor angiogenesis and prevents adhesion, invasion and metastasis of tumor cells [118]. $\mathrm{Rh}_{2}$ as an adjuvant agent was also tested in the nude mouse model with human ovarian cancer cells transplanted. In the presence of $\mathrm{Rh}_{2}$, cisplatin could significantly inhibit tumor growth in vivo and prolong survival time. Neither $\mathrm{Rh}_{2}$ nor cisplatin alone could inhibit tumor growth [119]. It was shown that chemotherapy supplemented with $\mathrm{Rh}_{2}$ is $60 \%$ more effective than chemotherapy alone. It could also mitigate the adverse effects of hair loss, anemia, nausea, vomit and poor appetite following chemotherapy or radiotherapy [120].

Both $\mathrm{Rg}_{3}$ and $\mathrm{Rh}_{2}$ are extracted from red ginseng which is processed by steaming and drying. During the process, the malonyl group at the C- 6 is released and the glycosyl moiety at C-20 is partially detached to generate $\mathrm{Rh}_{1}, \mathrm{Rh}_{2}$ and $\mathrm{Rg}_{3}$ through deglycosylation similar to the deglycosylated product, compound $\mathrm{K}$ generated from the metabolic transformation of ginsenoside $\mathrm{Rb}_{1}$ by intestinal bacteria $[121,122]$. However, whether all of the ginsenosides generated by such post-treatment of white ginseng have similar anti-tumor effects are still not known.

\section{Anti-angiogenic effects of ginsenosides}

Various ginsenosides including $\mathrm{Rg}_{3}, \mathrm{Rb}_{2}$ and compound $\mathrm{K}$ demonstrated anti-angiogenic activity in different tumor models. Among them, $\mathrm{Rg}_{3}$ is the most extensively investigated. It exerts an anti-angiogenic action in different animal models when administered alone or in combination 
with other conventional chemicals. In those animal models which have been orthotopically implanted with different tumor cells such as human breast infiltrating duct carcinoma, ovarian carcinoma SKOV3 cells, B16-BL6 melanoma cells and colon 26-M3.1 carcinoma, $\mathrm{Rg}_{3}$ or $\mathrm{Rb}_{2}$ was found to inhibit angiogenesis in vivo. A significant reduction of intra-tumoral microvessel density (MVD), VEGF mRNA and VEGF protein levels in tumor tissues and sera of the tumor-bearing animals was observed [104$106,122]$. Similar results were also reported when $\mathrm{Rg}_{3}$ was used in combination with a low dose of cyclophosphamide in bearing mice Lewis lung carcinoma [109]. These data indicate that one of the mechanisms of anti-metastatic effect of ginsenosides is probably related to suppression of tumor-induced angiogenesis [104].

In a recent study, we demonstrated that $20(\mathrm{R})-\mathrm{Rg}_{3}\left(1-10^{3}\right.$ $\mathrm{nM}$ ) was able to inhibit HUVEC proliferation, VEGFinduced chemoinvasion and tubulogenesis in vitro in a dose-dependent manner. In a Matrigel plug assay, 20(R)$\mathrm{Rg}_{3}(600 \mathrm{nM})$ was able to reduce the hemoglobin content by 5 -fold when compared with the positive control containing bFGF and heparin. The extent of microvascular sprouting was inhibited dose-dependently by $20(\mathrm{R})-\mathrm{Rg}_{3}$ in the ex vivo organtypic cultures of rat aortic ring fragments (Figure 5). Basement membrane degrading enzymes, especially MMP-2 and -9, are secreted by activated ECs (or even tumor cells) throughout the angiogenic process. They have been demonstrated to play a critical role in cell invasion and migration, as well as angiogenesis. Our data further demonstrate that the anti-angiogenic effect of $20(\mathrm{R})-\mathrm{Rg}_{3}$ was probably related to reduction of expression and activities of MMP-2 and -9 [124]. By using DNA microarray, $20(\mathrm{R})-\mathrm{Rg}_{3}$ was found to inhibit the protein expression of angiogenic factors via several target genes (e.g. VEGF, bFGF and MMP-2) in both human lung adenocarcinoma cell line A549 and HUVEC304 cells [123]. Current research findings, indicating that some PD type ginsenosides (e.g. $\mathrm{Rg}_{3}$ and $\mathrm{Rb}_{2}$ ) exhibit potent anti-tumor and anti-angiogenic activities in vitro and in vivo, have far-reaching implications for future development of ginsenosides as an anti-tumor medicine.

\section{Angiogenic effects of ginsenosides}

In contrast to the anti-angiogenic effects of ginsenosides such as $\mathrm{Rb}_{1}$ and $\mathrm{Rg}_{3}$, another group of ginsenosides, represented by the panaxatriols $\mathrm{Rg}_{1}$ and $\mathrm{Re}$, have been found to be angiogenic. $\mathrm{Rg}_{1}$ increased HUVEC proliferation, migration and tube formation in a dose-dependent manner [125-128]. We further demonstrated its angiogenic effects using the in vivo Matrigel plug and ex vivo aortic ring sprouting models (Figure 5). Histological evaluation of the Matrigel implants indicated that functional neovessels were formed as induced by $\mathrm{Rg}_{1}$. The in vivo data collected seven days after the implantation of genipin-fixed porous acellular bovine pericardium (same as extracellular matrices), which was dip-coated with $\mathrm{Re}$ or $\mathrm{Rg}_{1}$, indicate that the density of neovessels and tissue hemoglobin content inside the matrices were significantly increased by both ginsenosides. Furthermore, vascularized neo-connective tissue fibrils were found to fill the pores in the matrices loaded with Re [125]. Similar angiogenic activities were also observed in the above assays when $\mathrm{Rg}_{1}$ was used [126]. Interestingly, ginsenoside-induced angiogenesis was found to be comparable to or even better than bFGFinduced angiogenesis in vivo. These data suggest that both ginsenosides are very potent angiogenic agents and may potentially be useful in therapeutic angiogenesis in tissueengineering strategies

Ginseng contains two groups of ginsenosides with activity in the modulation of angiogenesis. These observed counteracting effects can be interpreted by the Yin/Yang theory in traditional Chinese medicine (TCM). In fact, we have, in our previous publications, demonstrated strong scientific evidence supporting the ancient Yin/Yang theory [129]. Administration of $\mathrm{Rg}_{1}$ or $\mathrm{Rb}_{1}$ alone was shown to exert counteracting effects in angiogenesis. $\mathrm{Rg}_{1}$ alone promoted functional neovascularization in the polymer scaffold in Matrigel implant model and the chemoinvasion of HUVEC. By contract, $\mathrm{Rb}_{1}$ exerted inhibition in both. Moreover, we found that ginseng extract reconstituted with a defined ratio of $\mathrm{Rg}_{1}$ and $\mathrm{Rb}_{1}$ could alter the angiogenic outcome. In an in vivo scaffold implant neovascularization model, administration of an extract with a higher concentration of $\mathrm{Rg}_{1}$ than $\mathrm{Rb}_{1}\left(\mathrm{Rg}_{1}: \mathrm{Rb}_{1}=5: 2\right)$ resulted in the induction of significant angiogenesis in the implant compared with control implants. In contrast, overabundance of $\mathrm{Rb}_{1}\left(\mathrm{Rg}_{1}: \mathrm{Rb}_{1}=2: 5\right)$ inhibited $\mathrm{Rg}_{1^{-}}$ induced neovascularization [130]. These counteracting actions manifested the logic of Yin/Yang theory of TCM, which advocates that everything has opposing Yin and Yang aspects, and these aspects are reciprocally regulated and inhibited by each other in such a way that a continuous state of dynamic balance is maintained. The contents of ginsenosides in $P$. ginseng, $P$. quinquefolius and $P$. notoginseng were then measured by an HPLC method. The data show that $P$. ginseng has a higher ratio of $\operatorname{Rg}_{1}$ to $\mathrm{Rb}_{1}(0.51$ - 2.08), while P. quinquefolius has a lower ratio (0.07 $1.4)[131,132]$. These findings are also consistent with the TCM's attributes of 'hot' (i.e. stimulating) properties of $P$. ginseng and 'cool' (i.e. calming) properties of $P$. quinquefolius.

\section{Functional genomics approach on the mechanistic study of ginsenoside}

Functional genomics refers to the functions and interactions of genes towards a holistic view of the biological system in terms of gene expression and proteins. It focuses on the dynamics of gene transcription, translation and 
(A)
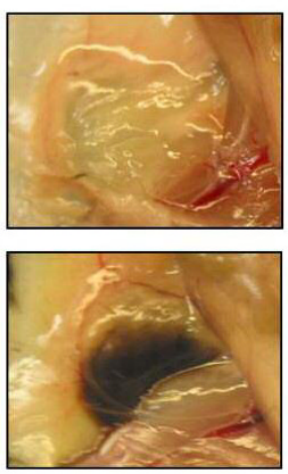

(C)
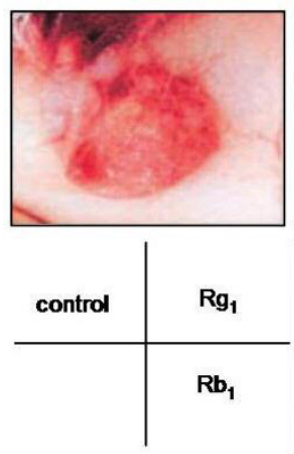
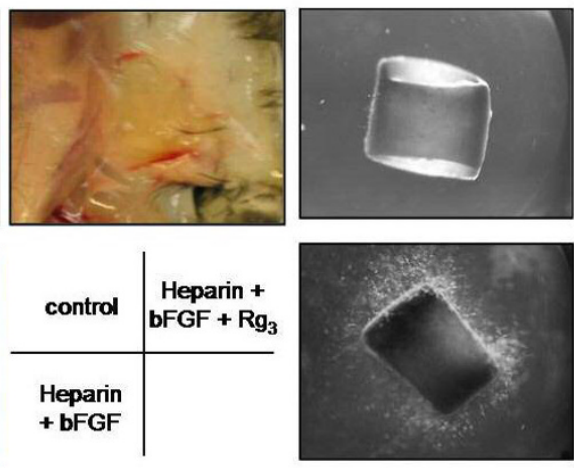

(D)
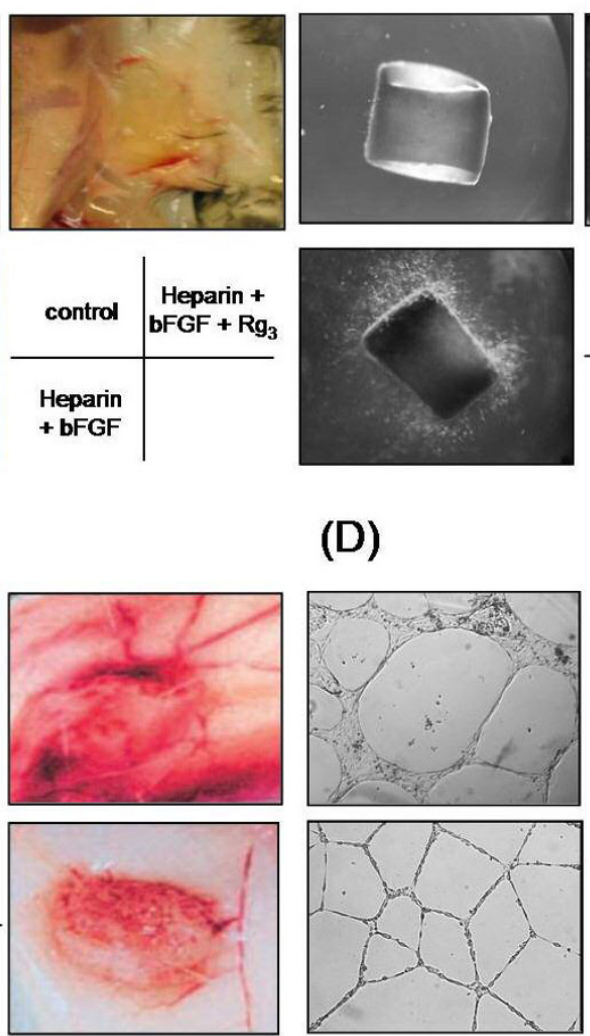

(B)
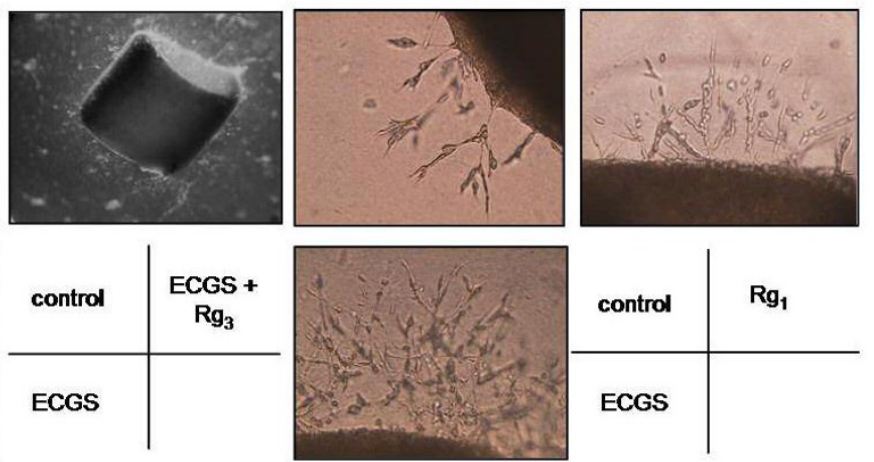
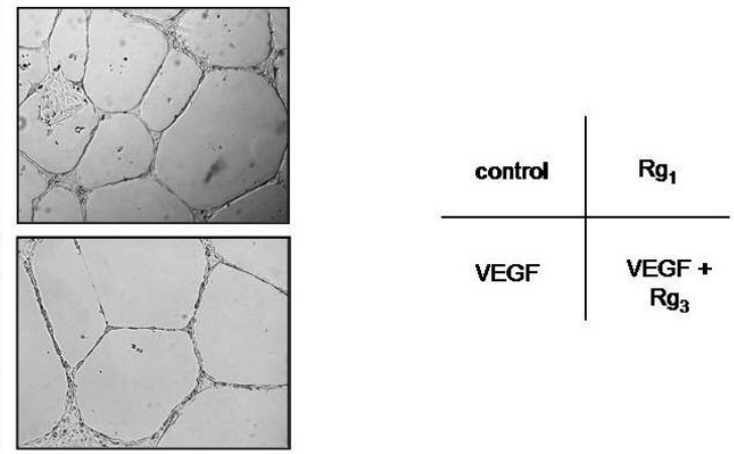

\section{Figure 5}

Angiogenesis assays. Angiogenesis is a multi-step process, Different types of in vitro, in vivo or ex vivo bioassays have been designed to mimic the various steps of angiogenesis. (A) In vivo Matrigel Plug assay: liquid form Matrigel (500 $\mu$ l) containing growth factor (e.g. bFGF) and/or ginsenoside is injected into the abdominal region of C57/BL mice subcutaneously. The Matrigel will solidify at $37^{\circ} \mathrm{C}$ and form a solid 'plug'. After 5 days of incubation, the mice are sacrificed and in vivo angiogenesis including endothelial cell invasion, migration and formation of neovessels can be examined [124]. (B) Ex vivo rat aortic ring sprouting assay: rat aortic fragments one millimeter in length are embedded in Matrigel and cultured in the presence of growth factors (e.g. endothelial cell growth supplements - ECGS) and/or ginsenosides. The extent of endothelial sprouting from the aortic fragment can clearly indicate the angiogenic properties of ginsenosides [I24]. (C) In vivo sponge implantation assay: a sterile polyether polyurethane sponge $\left(170 \mathrm{~mm}^{3}\right)$ containing ginsenosides is inserted into the abdominal region of Balb/c mice. After incubation for 15 days, the animals are euthanized and neovascularization is examined as indicated by the growth of vessels in the granuloma tissue [129]. (D) In vitro tube formation assay: endothelial cells are seeded on the Matrigel and subsequently incubated in medium containing growth factors (e.g. VEGF) and/or ginsenosides. Endothelial cells will rearrange and alight into a tubular structure. Angiogenic properties of ginsenosides can be reflected from the number of tubes, branching points or tube area.

protein-protein interactions, instead of the static views of genomic information (e.g. gene sequences). It can be achieved by means of transcriptomics (differential expression of genes), proteomics (the study of total protein complement of a genome), phosphoproteomics and metabolomics studies (the study of the entire metabolic content of a cell or an organism). In general, the functional genomics approach is accompanied by highthroughput technology platforms such as the DNA microarray (i.e. DNA chip) technology and two-dimensional gel electrophoresis (2-DE) coupled with mass spectrometry for characterization of the abundant gene and protein products. The chip-based microarray allows a quantitative parallel assessment of gene expression and facilitates the study of complicated drug actions at the molecular level. This rapid increase in functional genomic-based drug studies enables an early and more accurate prediction and diagnosis of disease and disease progression. Understanding of the individual responses to drugs will have implica- 
tions for their use and development by the pharmaceutical industry.

This approach was applied in the mechanistic study of ginsenoside $\mathrm{Rg}_{1}$ on HUVEC $[127,133]$. Our microarray data indicated that ginsenoside $\mathrm{Rg}_{1}$ could up-regulate a set of genes related to cell adhesion, migration and cytoskeleton such as RhoA, RhoB, IQ-motif-containing GTPaseactivating protein 1 (IQGAP1), calmodulin (CALM2), Vav2 and laminin- $\alpha 4$ (LAMA4) in HUVEC. These proteins interact with one another in a hierarchical cascade pattern in modulating cell architectural dynamics. As we observed in the tube formation assay, HUVEC undergo rapid migration and morphological differentiation to form tubular structures by involving a dynamic assembly and disassembly of cytoskeletons. RhoA and RhoB, which belong to Rho family GTPases, have been found to regulate cell-cell adhesion and hence the motility through interfering with membrane ruffling, stress fiber formation and E-cadherinmediated cell-cell adhesions [134-142]. The activities of GTPases are regulated by means of a molecular switch; cycling of the GDP-bound form (inactive state) and GTPbound form (active state). As demonstrated by Bustelo et al., such transformation can be activated by guanine nucleotide exchange factors (Rho-GEFs) $[143,144]$. Vav2, one of Rho-GEFs, can increase the exchange of boundGDP for a GTP molecule and translocate the Rho GTPases to the plasma membrane for interaction with its Rho effectors such as IQGAP1 [145]. Moreover, Vav2 can also affect cadherin-mediated cell-cell adhesion by binding with p120 catenin leading to formation of lamellipodia and membrane ruffling [146-148]. IQGAP1 acts as a negative regulator in E-cadherin-mediated cell-cell adhesion by interacting directly with $\beta$-catenin and the cytoplasmic domain of cadherin [149,150]. Over-expression of IQGAP1 is believed to compete with $\alpha$-catenin for the same binding site on $\beta$-catenin and displace $\alpha$-catenin from the $\beta$-catenin- $\alpha$-catenin complex which disrupts the association of the complex with F-actin. Such cytomechanical modifications can subsequently cause the reduction of E-cadherin-mediated cell-cell adhesion that accounts for the changes in cell morphology and migration [151]. Moreover, laminins, which are the trimeric basement membrane glycoproteins, have been found to participate in the formation and differentiation of tubular structures of HUVEC in vitro and to provide a structural link between the ECM and the actin-based cytoskeletal system of cells [152-156]. Undoubtedly, microarray technology provides a high throughput platform for the elucidation of drug mechanism in study models.

On a different front, a proteomic study was carried out by Ma et al. to elucidate the cardiovascular protective role of $\mathrm{Rg}_{1}$ on ECs [133]. The data show that protein expression of MEKK-3, reticulocalbin, phosphoglycerate, 6-phos- phogluconolactonase, zinc finger protein, NSAP1 protein, recombination-activating protein was increased, while that of eNOS, and mineralocorticoid receptor (MR) was decreased upon tumor necrosis factor- $\alpha$ (TNF- $\alpha$ ) stimulation of HUVEC. However, $\mathrm{Rg}_{1}$ restored the expression of these proteins to the normal level. Western blotting and RT-PCR further validated that NO production in such TNF- $\alpha$ induced condition was correlated to the increase of eNOS mRNA and protein expression. They suggest that the increase of $\mathrm{NO}$ is related to the protective role of $\mathrm{Rg}_{1}$ on TNF- $\alpha$ stimulated HUVEC.

\section{Ginsenosides and steroids \\ Steroid hormones and vascular homeostasis}

A critical function of the vasculature is to provide a nutritional supply to tissues and organs. In general, proper vascular homeostasis is controlled by capillary permeability modulation, vasodilation and angiogenesis [157-159]. All these activities can govern the rate of material exchange, transportation and the site of distribution so as to meet the physiological needs of the human body. Steroid hormones, such as glucocorticoids, estrogens, progestagens, mineralocorticoids and androgens, play an important role in such vascular modulation at the molecular, cellular and even systematic levels [160-164].

Among the various steroid hormones, estrogen is the most promising example used to elaborate the maintaining and protective roles of steroid hormones on vascular homeostasis and cardiovascular disorders. The growing evidence implicated that estrogen reduces the risk of atherosclerosis by (1) decreasing the serum levels of both total and lowdensity-lipoprotein (LDL) cholesterol, while raising those of high-density-lipoprotein (HDL) cholesterol and triglycerides; (2) interfering with the inflammatory processes (e.g. monocyte adherence and trans-endothelial migration on the endothelium) in the vasculature; and (3) acting as an antioxidant [165-168]. Furthermore, estrogen is also a potent vasodilator, and hypotensive agents that can induce vascular relaxation by producing an increase of endothelium-derived vasodilators (e.g. NO). Mechanistic studies clearly indicate that while estrogen binds with its corresponding steroid hormone receptor - estrogen receptor $(\mathrm{ER} \alpha$, and $\mathrm{ER} \beta)$, it may undergo either or both genomic and non-genomic actions inside the cells. Through the conventional pathway, activated-ER induces the gene transcription of eNOS, thereby increasing NO generation. Alternatively, through triggering the intracellular signaling (non-genomic) pathway, phosphorylated estrogen-bound ER (ligand-activated ER) has been found to induce rapid endothelial NO release via the PI3K-Aktdependent pathway in HUVEC $[169,170]$. Various ginsenosides have been shown to exhibit an estrogen-like activity by acting as a functional ligand of ER [171-174]. 


\section{Ginsenosides-mediated steroid-like activities}

Ginsenosides could exhibit their actions through plasma membrane, cytosol, or even in the nucleus. They can initiate their mode of actions by binding to the membrane receptors (e.g. ATPase pump, ion transporters and channels, voltage gated channels and G-proteins) and subsequently activating the associated downstream signaling cascades. As described in the previous section, ginsenosides are amphipathic in nature, they can intercalate into the plasma membrane resulting in the alteration of membrane fluidity and trigger a series of cellular responses. Binding with the intracellular steroid hormone receptors including glucocorticoid receptor (GR), estrogen receptor (ER), progesterone receptor (PR), androgen receptor (AR) and mineralocorticoid receptor (MR), using their hydrophobic 'steroid-like' backbone is another alternative to trigger cellular responses. Like other steroids, ginsenosides can gain access to the nuclear receptors, where they regulate gene transcription by binding with the specific gene response elements to activate the so called 'genomic pathway' $[175,176]$ (Figure 6).

A previous study indeed demonstrated that $\mathrm{Rg}_{1}$ can transactivate glucocorticoid response element (GRE)-luciferase activity by acting as a functional ligand of the GR [177]. Glucocorticoids (GCs) have been reported to activate the phosphatidylinositol-3 kinase (PI3K)/Akt pathway after binding with the GR [178]. Interestingly, our recent findings also indicate that $\operatorname{Rg}_{1}$ can act as GCs to increase the phosphorylation of GR, PI3K, Akt/PKB and eNOS, leading to an enhancement of NO production in HUVEC (Figure 7). Activation of eNOS was abolished by differential inhibition using RU486 (GR antagonist), LY294002 (PI3K inhibitor) and SH-6 (Akt inhibitor), indicating that $\mathrm{Rg}_{1}$ induced NO production from eNOS via the PI3K/Akt pathway. Moreover, knockout of GR by siRNA completely eliminated such reaction. Taken together, we concluded that such NO generation pathway was mediated through the activation of GR by ginsenoside $\operatorname{Rg}_{1}$ [179]. This nuclear receptor mediated response, which occurs within seconds or minutes upon stimulation and is independent of any transcriptional activity, is classified as the 'nongenomic' pathway $[175,176]$ (Figure 6).

In a later study, we discovered that the angiogenic $\operatorname{Rg}_{1}$ was able to enhance VEGF expression in ECs by increasing the level of $\beta$-catenin within the nucleus. We concluded that $\mathrm{Rg}_{1}$ induced increase of VEGF in HUVEC through activation of a PI3K/Akt $\rightarrow$ GSK3 $\beta \rightarrow \beta$-catenin/TCF pathway via GR [180]. In addition, the PI3K/Akt-mediated NO generation has been found in androgen-responsive LNCaP and estrogen-responsive MCF-7 cells by others [181]. Re was found to bind with steroid hormone receptors (including $\mathrm{AR}, \mathrm{ER} \alpha$ and PR). Lee et al., however, showed that ginse- noside $\mathrm{Rh}_{1}$ could only activate $\mathrm{ER}$ in the $\mathrm{CV}-1$ cell model [173].

The estrogen-like activity of various ginsenosides including $\mathrm{Rg}_{1}, \mathrm{Rh}_{1}$ and $\mathrm{Rb}_{1}$ has been reported [170-172]. In fact, ginseng has been used in TCM for alleviation of the symptoms of menopause, which means ginseng, probably ginsenosides, can act as phytoestrogens to elicit an ERmediated pathway for protecting the cardiovascular system. These recent research findings clearly indicate that ginsenosides may act as steroid hormones to activate various steroid hormone receptors to exert these pleiotropic responses. Although many mechanisms behind the physiological effects induced by ginsenosides are still not clear, their ability to interact with steroid hormone receptors may hold the key to finally elucidate these diverse actions of ginseng.

\section{Conclusion}

At present, ginseng is not only used as a therapeutic by traditional medical practitioners but is also as health supplements readily available in the commercial market. The diversity of highly desirable physiological effects of ginseng has intrigued scientists for years. In general, most of its pharmacological actions have been attributed to a group of triterpenoid saponins called ginsenosides. Although the modulatory effects of ginseng or probably ginsenosides have been extensively investigated, the actual molecular mechanisms remain largely unknown. Recently, it has been found that ginsenosides can act as functional ligands to activate different steroid hormone receptors. Through such mechanisms, ginseng can exert its effects on the human body by acting in a similar way as the steroid hormones. The interaction between ginsenosides and various nuclear steroid hormone receptors may explain the diverse activities of ginseng, which may eventually lead to further development of ginseng-derived therapeutics for angiogenesis-related diseases.

\section{Abbreviations}

2-DE: Two-dimensional gel electrophoresis

AR: Androgen receptor

BCRP: Breast cancer resistance protein

CALM2: Calmodulin

CNS: Central nervous system

ECM: Extracellular matrix

ECs: Endothelial cells

eNOS: Endothelial nitric oxide synthase 


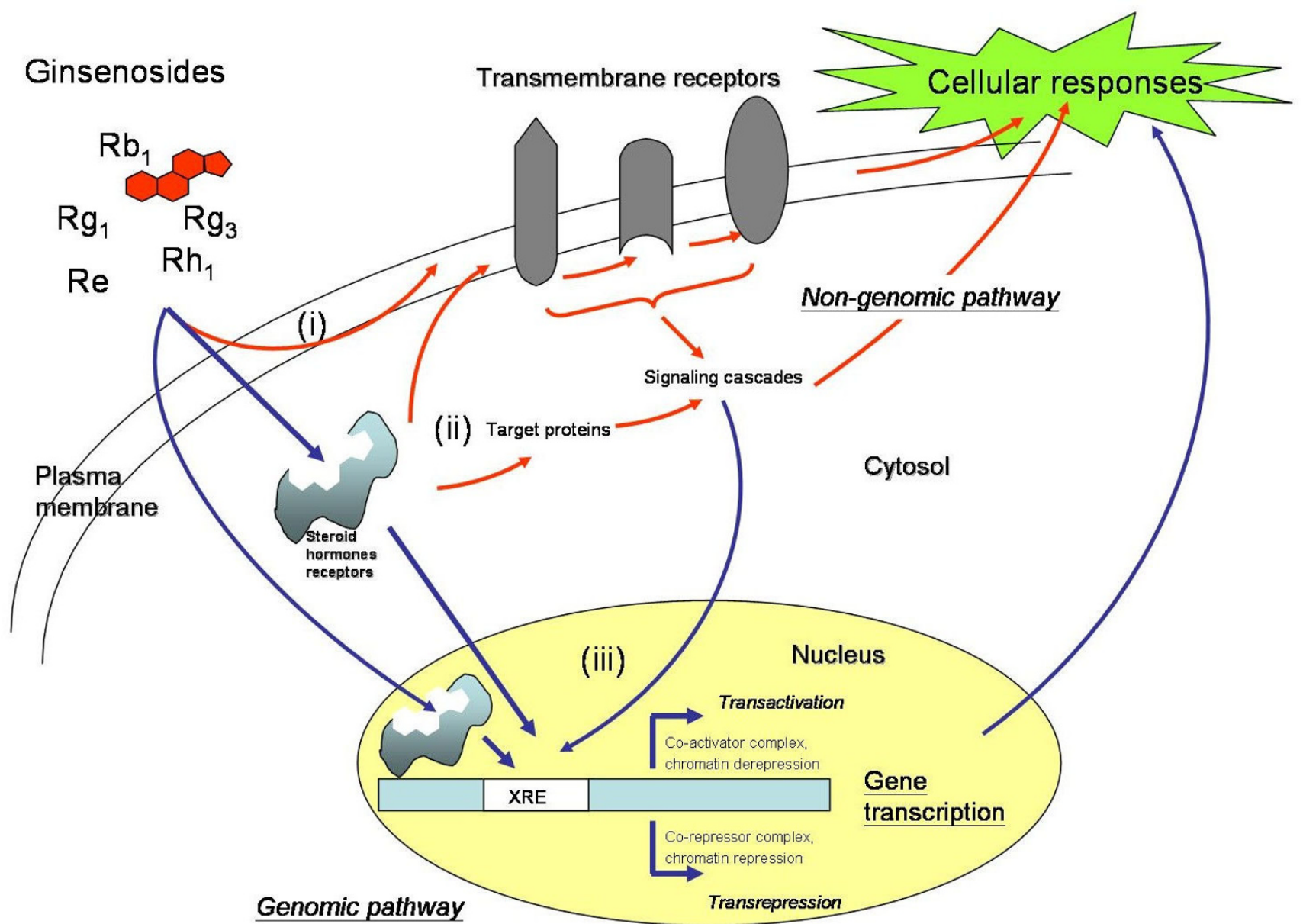

Figure 6

Schematic overview of ginsenosides-mediated genomic and non-genomic pathways. Ginsenosides possess a steroid-like skeleton composed of four trans-rings with different degrees of glyco-substitution. They are amphipathic in nature and can exhibit their actions at different cellular locations; such as the plasma membrane, cytosol and nucleus. Through the nongenomic pathway (indicated by red arrows), (i) they can initiate their actions by binding with the transmembrane receptors (e.g. ATPase pump, ion transporters and channels, voltage-gated channels and G-proteins) and subsequently activating the associated downstream signaling cascades. Moreover, they can intercalate into the plasma membrane resulting in an alteration of membrane fluidity and a trigger of a series of cellular responses. (ii) binding with steroid hormone receptors (SHRs) including glucocorticoid receptor (GR), estrogen receptor (ER), progesterone receptor (PR), androgen receptor (AR) and mineralocorticoid receptor (MR) present inside or outside the nucleus by using their hydrophobic backbone is another alternative to trigger downstream cellular responses. Those activated (phosphorylated) SHRs can activate the target molecules through a signaling cascade that brings about various cellular responses. (iii) the ligand-bound SHRs can translocate into the nucleus, where they regulate gene transcription by binding with the specific Response Elements (XRE). This is the so called 'genomic pathway' (indicated by blue arrows). Consequently, the altered gene products can affect the final cellular responses.

ER: Estrogen receptor

FGF: Fibroblast growth factor

GC: Glucocorticoids

GR: Glucocorticoid receptor

GRE: Glucocorticoid responsive element
HDL: High-density-lipoprotein

HUVEC: Human umbilical vein endothelial cells

ICAM-1: Intercellular adhesion molecule-1

IQGAP1: IQ-motif-containing GTPase-activating protein 1 


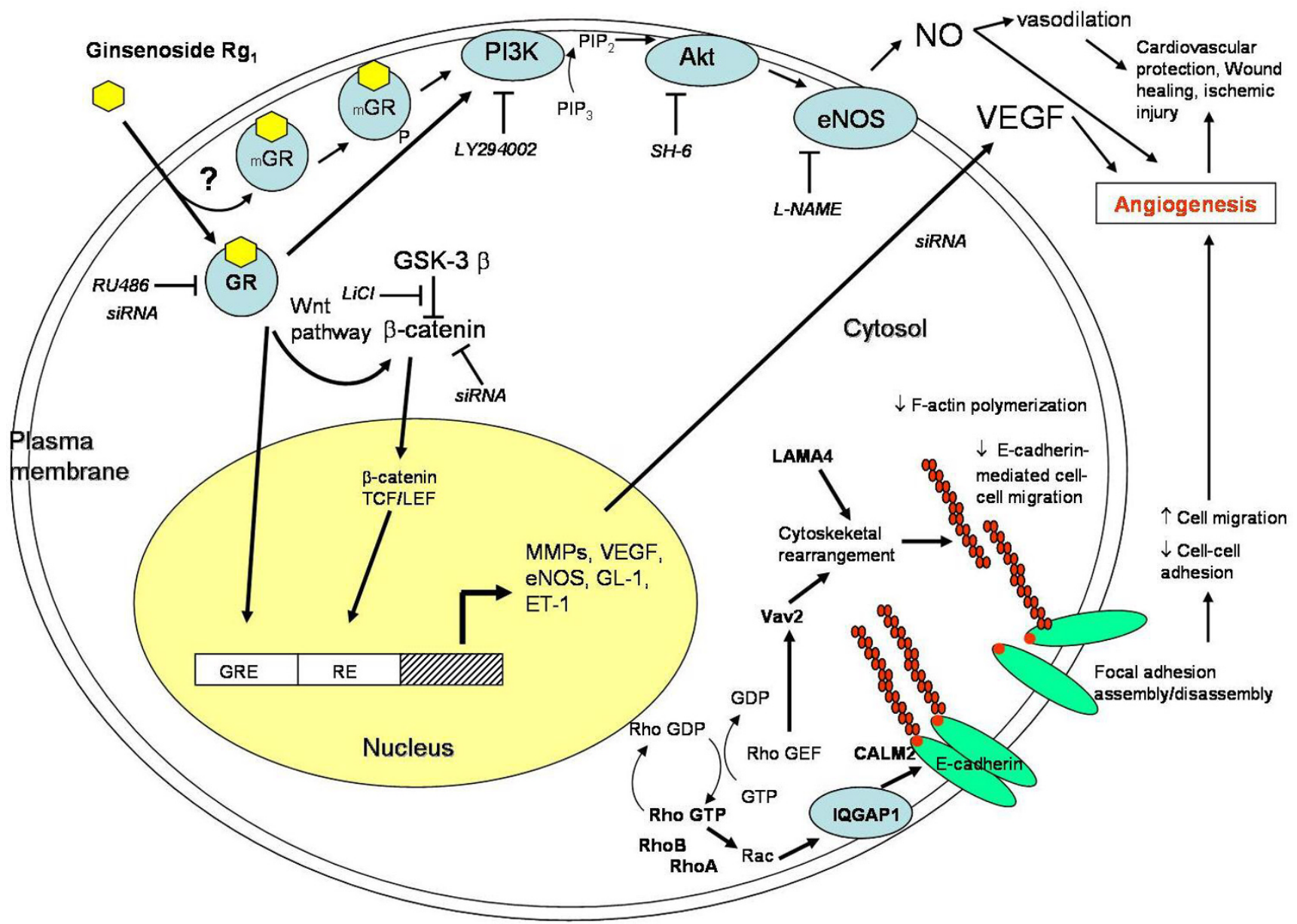

Figure 7

Schematic overview of ginsenoside $\mathbf{R g}_{1}$-mediated angiogenic action in HUVEC. Ginsenoside $\mathrm{Rg}_{1}$, which acts as a functional ligand of glucocorticoid receptor (GR) (either cytosol GR or membrane-bound GR-mGR), promotes angiogenesis through both non-genomic and genomic pathways. Through the non-genomic pathway, it increases nitric oxide (NO) production via the PI3K-Akt pathway: GR $\rightarrow$ phosphatidylinositol-3 kinase (PI3K)/Akt pathway $\rightarrow$ endothelial nitric oxide synthase (eNOS) pathway. $\mathrm{Rg}_{1}$ also increases vascular endothelial growth factor (VEGF) production through the GR $\rightarrow$ PI3K/Akt $\rightarrow$ GSK3 $\beta \rightarrow \beta$-catenin/TCF pathway. Gene expression profiling data indicated that $R g_{1}$ could increase the expression of a group of genes (e.g. Rho A, RhoB, IQGAPI, LAMA4, CALM2 and Vav2) which are related to cell-cell adhesion, migration and cytoskeletal remodeling.

LAMA4: Laminin- $\alpha 4$

LDL: Low-density-lipoprotein

L-NAME: $\mathrm{N}^{\omega}{ }^{\omega}$-nitro-L-arginine methylester

MDR: Multi-drug resistance

MMPs: Matrix metalloproteinases

MR: Mineralocorticoid receptor
MVD: Microvessel density

MX: Mitoxantrone

OH: Hydroxyl

PA: Plasminogen activators

PAI-1: Plasminogen activator inhibitor-1

Pgp: P-glycoprotein 
PKC: Protein kinase C

PPD: Protopanaxadiols

PPT: Protopanaxatriols

PR: Progesterone receptor

RE Responsive element

Rho-GEFs: Guanine nucleotide exchange factors

Rx: Ginsenosides

TCM: Traditional Chinese medicine

TGF- $\beta$ : Transforming growth factor $\beta$

TNF- $\alpha$ : Tumor necrosis factor $\alpha$

uPA: Urokinase plasminogen activator

uPAR: Urokinase plasminogen activator receptor

VCAM-1: Vascular cell adhesion molecule-1

VEGF: Vascular endothelial growth factor

\section{Competing interests}

The author(s) declare that they have no competing interests.

\section{Authors' contributions}

PYKY conceived and wrote the article and performed the experiments. NKM and TBN drafted the section of 'antitumor effects of ginsenosides'. YKC prepared all the chemical structures of ginsenosides. KWL and TPDF conducted the experiments. HWY and RNSW helped to compile the manuscript.

\section{Acknowledgements}

The present work was supported by earmarked research grant (HKBU 2171/03M and HKBU 2476/06M) from the Research Grant Council, Hong Kong SAR Government and a faculty research grant (FRG/04-05/II-36) from the Hong Kong Baptist University.

\section{References}

I. Hu SY: A contribution of our knowledge of ginseng. Am J Chin Med 1977, 5: I-23.

2. Tao HC: Sheng-Nung-Pen-Tsao-Ching Taipei, Taiwan: Chung-Hwa; 1955.

3. Liu CX: Introduction on research of ginseng. Information of Traditional Chinese Medicine 1975, 2:9-II.

4. Liu CX: Pharmacology and clinic of active principles of ginseng. Chinese Traditional Herbs and Drugs 1975, 7:57.

5. Liu CX, Xiao PG: Recent advances on ginseng research in China. I Ethnopharmacol 1992, 36:27-38.

6. Jiang JW, Xiao QS: Handbook of Active Constituents of Medicinal Plants Beijing: People's Health Publishers; 1985:503-5I6.
7. Wang BX: Progress of pharmacological studies of ginseng. Yaoxue Xuebao 1980, 15:312-320.

8. Yun TK: Brief introduction of Panax gingeng C.A. Meyer. J Korean Med Sci 200I:3-5.

9. Wen J, Zimmer EA: Phylogeny and biogeography of Panax L. (the ginseng genus, araliaceae): inferences from ITS sequences of nuclear ribosomal DNA. Mol Phylogenet Evol 1996, 6:167-177.

10. Lee FC: Facts about Ginseng. In The Elixir of Life Elizabeth, NJ: Hollyn International Corp; 1992.

II. Huang KC: The Pharmacology of Chinese Herbs Boca Raton, FL: CRC Press; 1999.

12. Shoji J: Recent advances in the chemical studies on ginseng. In Advances in Chinese Medicinal Materials Research Edited by: Chang HM Yeung HW, Tso WW, Koo A. Singapore: World Scientific; 1985.

13. Tanaka $O$, Kasai $R$, Morita $T$ : Chemistry of ginseng and related plants: recent advances. Abstr Chin Med 1986, I: I30-152.

14. Wang X, Sakuma T, Asafu-Adjaye E, Shiu GK: Determination of ginsenosides in plant extracts from Panax ginseng and Panax quinquefolius L. by LC/MS/MS. Anal Chem 1999, 7 I:I579-I 584.

15. Yu H, Zhang C, Lu M, Sun F, Fu Y, Jin F: Purification and characterization of new special ginsenosidase hydrolyzing multiglycisides of protopanaxadiol ginsenosides, ginsenosidase type I. Chem Pharm Bull (Tokyo) 2007, 55:23 I-235.

16. Banthorpe DV: Terpenoid. In Natural Product Edited by: Mann J. Essex: Longman Scientific and Technical; 1994:331-339.

17. Hertig AT: Contrib. Embryol 1935, 25:37.

18. Folkman J, Shing Y: Angiogenesis. J Biol Chem 1992 , 267: $10931-10934$.

19. Risau W: Mechanism of angiogenesis. Nature 1997, 386:671-674.

20. Folkman J, Klagsbrun M: Angiogenic factor. Science 1987, 235:442-447.

21. Pepper MS: Role of the matrix matelloproteinases and plasminogen activator-plasmin system in angiogenesis. Arterioscler Thrombovasc Biol 200 I, 2 I : I I04- I I I7.

22. Eliceiri BP, Cheresh DA: The role of alphav integrins during angiogenesis: insights into potential mechanisms of action and clinical development. J Clin Invest 1999, I03: I227-1 230.

23. Patan S, Haenni B, Burri PH: Implementation of intussusceptive microvascular growth in the chicken chorioallantoic membrane (CAM). Microvasc Res 1997, 53:33-52.

24. Djonov V, Schmid M, Tschanz SA, Burri PH: Intussusceptive angiogenesis: its role in embryonic vascular network formation. Circ Res 2000, 86:286-292.

25. Djonov $\mathrm{V}$, Baum $\mathrm{O}$, Burri $\mathrm{PH}$ : Vascular remodeling by intussusceptive angiogenesis. Cell Tissue Res 2003, 3 I 4: I07-I I7.

26. Veikkola T, Alitalo K: VEGFs, receptors and angiogenesis. Semin Cancer Biol 1999, 9:2 I I-220.

27. Marchio S, Primo L, Pagano M, Palestro G, Albini A, Veikkola T, Cascone I, Alitalo K, Bussolino F: VEGFs, receptors and angiogenesis. Semin Cancer Biol 1999, 9:2 II-220.

28. Pepper MS, Ferrara N, Orci L, Montesano R: Potent synergism between vascular endothelial growth factor and basic fibroblast growth factor in the induction of angiogenesis in vitro. Biochem Biophys Res Commun 1992, I 89:824-83I.

29. Unemori EN, Ferrara N, Bauer EA, Amento EP: Vascular endothelial growth factor induces interstitial collagenase expression in human endothelial cells. J Cell Physiol 1992, I 53:557-62.

30. Mandriota SJ, Seghezzi G, Vassalli JD, Ferrara N, Wasi S, Mazzieri R, Mignatti P, Pepper MS: Vascular endothelial growth factor increases urokinase receptor expression in vascular endothelial cells. J Biol Chem 1995, 270:9709-97I6.

31. Ferrara N, Carver-Moore K, Chen H, Dowd M, Lu L, O'Shea KS, Powell-Braxton L, Hillan KJ, Moore MW: Heterozygous embryonic lethality induced by targeted inactivation of the VEGF gene. Nature 1996, 380:439-442.

32. Carmeliet P, Ferreira V, Breier G, Pollefeyt S, Kieckens L, Gertsenstein M, Fahrig M, Vandenhoeck A, Harpal K, Eberhardt C, Declercq C, Pawling J, Moons L, Collen D, Risau W, Nagy A: Abnormal blood vessel development and lethality in embryos lacking a single VEGF allele. Nature 1996, 380:435-439.

33. Hood JD, Meininger C], Ziche M, Granger HJ: VEGF upregulates ecNOS message, protein and NO production in human endothelial cells. Am J Physiol 1998, 274:HI054- I058.

34. van der Zee R, Murohara T, Luo Z, Zollmann F, Passeri J, Lekutat C, Isner JM: Vascular endothelial growth factor/vascular perme- 
ability factor augments nitric oxide release from quiescent rabbit and human vascular endothelium. Circulation 1997, 95:1030-1037.

35. Inoue N, Venema RC, Sayegh HS, Ohara Y, Murphy TJ, Harrison DG: Molecular regulation of the bovine endothelial cell nitric oxide synthase by transforming growth factor-beta I. Arterioscler Thromb Vasc Biol 1995, I 5: | 255-126I.

36. Wu HM, Yuan Y, McCarthy M, Granger HJ: Acidic and basic FGFs dilate arterioles of skeletal muscle through a NO-dependent mechanism. Am J Physiol 1996, 27 I:HI087-1093.

37. Babaei S, Teichert-Kuliszewska K, Monge JC, Mohamed F, Bendeck MP, Stewart DJ: Role of nitric oxide in the angiogenic response in vitro to basic fibroblast growth factor. Circ Res 1998, 82:1007-1015.

38. Papapetropoulos A, Garcia-Cardena G, Madri JA, Sessa WC: Nitric oxide production contributes to the angiogenic properties of vascular endothelial growth factor in human endothelial cells. J Clin Invest 1997, 100:3131-3139.

39. Ziche M, Morbidelli L, Masini E, Amerini S, Granger HJ, Maggi CA, Geppetti $P$, Ledda F: Nitric oxide mediates angiogenesis in vivo and endothelial cell growth and migration in vitro promoted by substance P. J Clin Invest 1994, 94:2036-2044

40. Morbidelli L, Chang CH, Douglas JG, Granger HJ, Ledda F, Ziche M: Nitric oxide mediates mitogenic effect of VEGF on coronary venular endothelium. Am J Physiol 1996, 270:H4 I I-4I 5.

41. Dimmeler S, Hermann C, Galle J, Zeiher AM: Upregulation of superoxide dismutase and nitric oxide synthase mediates the apoptosis-suppressive effects of shear stress on endothelial cells. Arterioscler Thromb Vasc Biol 1999, 19:656-664.

42. Rossig L, Fichtlscherer B, Breitschopf K, Haendeler J, Zeiher AM, Mulsch A, Dimmeler S: Nitric oxide inhibits caspase-3 by S-nitrosation in vivo. J Biol Chem 1999, 274:6823-6826.

43. Ziche M, Parenti A, Ledda F, Dell'Era P, Granger HJ, Maggi CA, Presta $M$ : Nitric oxide promotes proliferation and plasminogen activator production by coronary venular endothelium through endogenous bFGF. Circ Res 1997, 80:845-852.

44. Noiri E, Lee E, Testa J, Quigley J, Colflesh D, Keese CR, Giaever I, Goligorsky MS: Podokinesis in endothelial cell migration: role of nitric oxide. Am J Physiol 1998, 274:C236-244.

45. Dulak J, Jozkowicz A, Dembinska-Kiec A, Guevara I, Zdzienicka A Zmudzinska-Grochot D, Florek I, Wojtowicz A, Szuba A, Cooke JP: Nitric oxide induces the synthesis of vascular endothelial growth factor by rat vascular smooth muscle cells. Arterioscle Thromb Vasc Biol 2000, 20:659-666.

46. Lala PK, Chakraborty C: Role of nitric oxide in carcinogenesis and tumor progression. Lancet Oncol 200I, 2: I49-I56.

47. Cooke JP, Dzau VJ: Nitric oxide synthase: role in the genesis of vascular disease. Annu Rev Med 1997, 48:489-509.

48. Cooke JP, Dzau VJ: Derangements of the nitric oxide synthase pathway, L-arginine and cardiovascular diseases. Circulation 1997, 96:379-382

49. Oemar BS, Tschudi MR, Godoy N, Brovkovich V, Malinski T, Luscher TF: Reduced endothelial nitric oxide synthase expression and production in human atherosclerosis. Circulation 1998, 97:2494-2498.

50. Frank S, Madlener M, Pfeilschifter J, Werner S: Induction of inducible nitric oxide synthase and its corresponding tetrahydrobiopterin-cofactor-synthesizing enzyme GTPcyclohydrolase I during cutaneous wound repair. J Invest Dermatol 1998, I I I:1058-1064.

5I. Frank S, Stallmeyer B, Kampfer H, Kolb N, Pfeilschifter J: Nitric oxide triggers enhanced induction of vascular endothelial growth factor expression in cultured keratinocytes (HaCaT) and during cutaneous wound repair. FASEB J 1999, 13:2002-2014

52. Leibovich SJ, Chen JF, Pinhal-Enfield G, Belem PC, Elson G, Rosania A, Ramanathan M, Montesinos C, Jacobson M, Schwarzschild MA, Fink JS, Cronstein B: Synergistic up-regulation of vascular endothelial growth factor expression in murine macrophages by adenosine $\mathbf{A}(2 \mathrm{~A})$ receptor agonists and endotoxin. Am J Pathol 2002, I 60:223|-2244.

53. Xiong M, Elson G, Legarda D, Leibovich S]: Production of vascular endothelial growth factor by murine macrophages: regulation by hypoxia, lactate and the inducible nitric oxide synthase pathway. Am J Pathol 1998, I 53:587-598.
54. Yla-Herttuala S, Martin JF: Cardiovascular gene therapy. Lancet 2000, 355:213-222

55. Tonnesen MG, Feng X, Clark RAF: Angiogenesis in wound healing. J Investig Dermatol Symp Proc 2000, 5:40-46.

56. Brown LF, Yeo KT, Berse B: Expression of vascular permeability factor (VEGF) by epidermal keratinocytes during wound healing. J Exp Med 1992, I 76: I 375-1379.

57. Nissen NN, Polverini PJ, Koch AE, Volin MV, Gamelli RL, DiPietro LA: VEGF mediates angiogenic activity during the proliferative phase of wound healing. Am J Pathol |998, I 52:|445-| 452.

58. Fraser HM, Lunn SF: Regulation and manipulation of angiogenesis in the primate corpus luteum. Reproduction 200I, I 2 I:355-362.

59. Gargett CE, Rogers AW: Human endometrial angiogenesis. Reproduction 2001, I2 I:|8|-186.

60. Folkamn J: Tumor angiogenesis. Advance in Cancer Research 1974 , 19:331-358.

61. Walsh DA: Angiogenesis and arthritis. Rheumatology 1999 , 38: $103-112$

62. Folkman J: Angiogenesis in cancer, vascular, rheumatoid and other diseases. Nat Med 1995, I:27-31.

63. Carmeliet P, Jain RK: Angiogenesis in cancer and other diseases. Nature 2000, 407:249-257.

64. Bergers G, Benjamin LE: Tumorigenesis and the angiogenic switch. Nat Rev Cancer 2003, 3:401-4I0.

65. Raghu K: Basement membranes: structure, assembly and role in tumor angiogenesis. Nat Med 2003, 3:442-433.

66. Moulton KS: Angiogenesis in atherosclerosis: gathering evidence beyond speculation. Curr Opin Lipidol 2006, I 7:548-555.

67. Fukuda S, Yoshii S, Kaga S, Matsumoto M, Kugiyama K, Maulik N: Angiogenic strategy for human ischemic heart disease: brief overview. Mol Cell Biochem 2004, 264: I43-I49.

68. Aoki M, Morishita R: Therapeutic angiogenesis for ischemic diseases. Nippon Rinsho 2006, 64:762-768.

69. Fan TP, Kohn EC, Eds: The New Angiotherapy Totowa, NJ, USA: Human Press; 2002

70. Kerbel RS: Tumor angiogenesis: past, present and the near future. Carcinogenesis 2000, 21:505-5I5.

7I. Brekken RA, Li C, Kumar S: Strategies for vascular targeting in tumors. Int / Cancer 2002, I 00: | 23-130.

72. Ruoslahti E: Specialization of tumor vasculature. Nat Rev Cancer 2002, 2:83-90.

73. Doggrell SA: Pegaptanib: the first antiangiogenic agent approved for neovascular macular degeneration. Expert Opin Pharmacother 2005, 6:1421-1423.

74. Hori A, Ikeyama S, Sudo K: Suppression of cyclin DI mRNA expression by the angiogenesis inhibitor TNP-470 (AGM1470) in vascular endothelial cells. Biochem Biophys Res Commun 1994, 204: 1067-1073.

75. Masiero L, Figg WD, Kohn EC: New anti-angiogenesis agents: review of the clinical experience with carboxyamido-triazole (CAI), thalidomide, TNP-470 and interleukin-I2. Angiogenesis 1997, I:23-35.

76. Kohn EC: Endostatin and angiostatin: the next anti-angiogenesis generation. Angiogenesis 1998, 2:25-27

77. Bras M, Queenan B, Susin SA: Programmed cell death via mitochondria: different modes of dying. Biochemistry (Mosc.) 2005, 70:231-239.

78. Broker LE, Kruyt FA, Giaccone G: Cell death independent of caspases: a review. Clin Cancer Res 2005, I I:3155-3 I62.

79. Edinger AL, Thompson CB: Death by design: apoptosis, necrosis and autophagy. Curr Opin Cell Biol 2004, 16:663-669.

80. Cheng CC, Yang SM, Huang CY, Chen JC, Chang WM, Hsu SL: Molecular mechanisms of ginsenoside Rh2-mediated GI growth arrest and apoptosis in human lung adenocarcinoma A549 cells. Cancer Chemother Pharmacol 2005, 55:531-540.

8I. Kim HS, Lee EH, Ko SR, Choi KJ, Park JH, Im DS: Effects of ginsenosides Rg3 and Rh2 on the proliferation of prostate cancer cells. Arch Pharm Res 2004, 27:429-435.

82. Liu K, Xu SX, Che CT: Anti-proliferative effect of ginseng saponins on human prostate cancer cell line. Life Sci 2000, 67:1297-1306.

83. Nakata H, Kikuchi Y, Tode T, Hirata J, Kita T, Ishii K, Kudoh K, Nagata I, Shinomiya N: Inhibitory effects of ginsenoside Rh2 on tumor growth in nude mice bearing human ovarian cancer cells. Jpn J Cancer Res 1989, 89:733-740. 
84. Kim YS, Jin SH, Lee YH, Kim SI, Park JD: Ginsenoside Rh2 induces apoptosis independently of Bcl-2, Bcl-xL, or Bax in C6Bu-I cells. Arch Pharm Res 1999, 22:448-453.

85. Kim ND, Kang SY, Kim MJ, Park JH, Schini-Kerth VB: The ginsenoside Rg3 evokes endothelium-independent relaxation in rat aortic rings: role of $\mathbf{K}+$ channels. Eur J Pharmacol 1999, 367:51-57.

86. Kim ND, Kang SY, Park JH, Schini-Kerth VB: Ginsenoside Rg3 mediates endothelium-dependent relaxation in response to ginsenosides in rat aorta: role of $\mathbf{K}+$ channels. Eur J Pharmacol 1999, 367:41-49.

87. Kim HE, Oh JH, Lee SK, Oh YJ: Ginsenoside RH-2 induces apoptotic cell death in rat $\mathrm{C} 6$ glioma via a reactive oxygen- and caspase-dependent but BCl-X(L)-independent pathway. Life Sci 1999, 65:PL33-40.

88. Oh SH, Lee $\mathrm{BH}$ : A ginseng saponin metabolite-induced apoptosis in HepG2 cells involves a mitochondria-mediated pathway and its downstream caspase- 8 activation and Bid cleavage. Toxicol Appl Pharmacol 2004, 194:22 I-229.

89. Kim S, Lee YH, Park JH, Lee SK: Ginsenoside Rs4, a new type of ginseng saponin, concurrently induces apoptosis and selectively elevates protein levels of p53 and p2IWAF I in human hepatoma SK-HEP-I cells. Eur J Cancer 1999, 35:507-5 I I.

90. Li X, Guan YS, Zhou XP, Sun L, Liu Y, He Q, Fu L, Mao YQ: Anticarcinogenic effect of $20(R)$-ginsenoside $R g 3$ on induced hepatocellular carcinoma in rats. Sichuan Daxue Xuebao Yixue Ban 2005, 36:217-220.

91. Kang KA, Kim YW, Kim SU, Chae S, Koh YS, Kim HS, Choo MK, Kim $\mathrm{DH}$, Hyun JW: GI phase arrest of the cell cycle by a ginseng metabolite, compound $\mathrm{K}$, in $\mathbf{U} 937$ human monocytic leukamia cells. Ach Pharm Res 2005, 28:685-690.

92. Lee KY, Park JA, Chung E, Lee YH, Kim SI, Lee SK: GinsenosideRh2 blocks the cell cycle of SK-HEP-I cells at the GI/S boundary by selectively inducing the protein expression of p27kip I. Cancer Lett 1996, I I 0:193-200.

93. Fujikawa-yamamoto K, Ota T, Odashima S, Abe H, Arichi S: Different response in cell cycle of tumor cells to ginsenoside $R \mathbf{h} \mathbf{2}$. Cancer J 1987, I:349-352.

94. Popovich DG, Kitts DD: Ginsenosides 20(S)-protopanaxadiol and $R \mathbf{R} 2$ reduce cell proliferation and increase sub-G I cells in two cultured intestinal cell lines, Int-407 and Caco-2. Can J Physiol Pharmacol 2004, 82: 183-190.

95. Oh M, Choi YH, Choi S, Chung H, Kim K, Kim SI, Kim DK, Kim ND: Anti-proliferating effects of ginsenoside Rh2 on MCF-7 human breast cancer cells. Int J Oncol 1999, I 4:869-875.

96. Leung KN, Mak NK, Fung MC: Cytokines in the differentiation therapy of leukemia: from laboratory investigations to clinical applications. Crit Rev Clin Lab Sci 2005, 42:473-5I4.

97. Zeng XL, Tu ZG: In vitro induction of differentiation by ginsenoside Rh2 in SMMC-772I hepatocarcinoma cell line. Pharmacol Toxicol 2003, 93:275-283.

98. Zeng XL, Tu ZG: Induction of differentiation by ginsenoside Rh2 in hepatocarcinoma cell SMMC-772I. Ai Zheng 2004, 23:879-884

99. Xia LJ, Han R: Differentiation of B I 6 melanoma cells induced by ginsenoside RH2. Yaoxue Xuebao 1996, 3 I:742-745.

100. Lee YN, Lee HY, Chung HY, Kim SI, Lee SK, Park BC, Kim KW: In vitro induction of differentiation by ginsenoides in $\mathrm{F9}$ teratocarcinoma cells. Eur / Cancer |996, 32A:|420-|428.

I0I. Fujimoto J, Sakaguchi H, Aoki I, Toyoki H, Khatun S, Tamaya T: Inhibitory effect of ginsenoside-Rb2 on invasiveness of uterine endometrial cancer cells to the basement membrane. Eur J Gynaecol Oncol 200I, 22:339-34I.

102. Park MT, Cha HJ, Jeong JW, Kim SI, Chung HY, Kim ND, Kim OH, Kim KW: Glucocorticoid receptor-induced down-regulation of MMP-9 by ginseng components, PD and PT contributes to inhibition of the invasive capacity of HT 1080 human fibrosarcoma cells. Mol Cells 1999, 9:476-483.

103. Shinkai K, Akedo H, Mukai M, Imamura F, Isoai A, Kobayashi M, Kitagawa I: Inhibition of in vitro tumor cell invasion by ginsenoside Rg3. Jpn J Cancer Res 1996, 87:357-362.

104. Mochizuki M, Yoo YC, Matsuzawa K, Sato K, Saiki I, Tono-oka S, Samukawa K, Azuma I: Inhibitory effect of tumor metastasis in mice by saponins, ginsenoside-Rb2, 20(R)- and 20(S)-ginsenoside-Rg3, of red ginseng. Biol Pharm Bull 1995, I 8: I I97-I 202.
105. Sato K, Mochizuki M, Saiki I, Yoo YC, Samukawa K, Azuma I: Inhibition of tumor angiogenesis and metastasis by a saponin of Panax ginseng, ginsenoside-Rb2. Biol Pharm Bull 1994, 1 7:635-639.

106. Chen D, Zhao Y, Bai S, Shi Z, Zhang J: Effect of ginsenoside Rg3 on the progression of orthotopically xenotransplanted human breast cancer in nude mice and its mechanism. Sichuan Daxue Xuebao Yixue Ban 2003, 34:546-548.

107. Tao H, Yao M, Zou S, Zhao D, Qiu H: Effect of angiogenesis inhibitor $\mathbf{R g} 3$ on the growth and metastasis of gastric cancer in SCID mice. Zhonghua Waike Zazhi 2002, 40:606-608.

108. Li X, Guan YS, Zhou XP, Sun L, Liu Y, He Q, Fu L, Mao YQ: Anticarcinogenic effect of $\mathbf{2 0}(R)$-ginsenoside $R \mathbf{g} 3$ on induced hepatocellular carcinoma in rats. Sichuan Daxue Xuebao Yixue Ban 2005, 36:217-220.

109. Kang XM, Zhang QY, Tong DD, Zhao W: Experimental study on anti-angiogenesis in mice with Lewis lung carcinoma by lowdose of cyclophosphamide combined with ginsenoside Rg3. Zhongguo Zhongxiyi Jiehe Zazhi 2005, 25:730-733.

I I0. Mayer LD, Shabbits JA: The role for liposomal drug delivery in molecular and pharmacological strategies to overcome multidrug resistance. Cancer Metastasis Rev 200I, 20:87-93.

III. Ramachandran C, Rabi T, Fonseca HB, Melnick S], Escalon EA: Novel plant triterpenoid drug amooranin overcomes multidrug resistance in human leukemia and colon carcinoma cell lines. Int J Cancer 2003, I 05:784-789.

I 12. Szabo D, Keyzer H, Kaiser HE, Molnar J: Reversal of multidrug resistance of tumor cells. Anticancer Res 2000, 20:426I-4274.

I 13. Choi CH, Kang G, Min YD: Reversal of P-glycoprotein-mediated multidrug resistance by protopanaxatriol ginsenosides from Korean red ginseng. Planta Med 2003, 69:235-240.

I 14. Kim SW, Kwon HY, Chi DW, Shim JH, Park JD, Lee YH, Pyo S, Rhee DK: Reversal of P-glycoprotein-mediated multidrug resistance by ginsenoside Rg(3). Biochem Pharmacol 2003, 65:75-82.

I 15. Hasegawa H, Sung JH, Matsumiya S, Uchiyama M, Inouye Y, Kasai R, Yamasaki K: Reversal of daunomycin and vinblastine resistance in multidrug-resistant P388 leukemia in vitro through enhanced cytotoxicity by triterpenoids. Planta Med 1995, 61:409-413.

I 16. Berek L, Szabo D, Petri IB, Shoyama Y, Lin YH, Molnar J: Effects of naturally occurring glucosides, solasodine glucosides, ginsenosides and parishin derivatives on multidrug resistance of lymphoma cells and leukocyte functions. In Vivo 200I, I5:|5|-156.

I 17. Jin J, Shahi S, Kang HK, van Veen HW, Fan TP: Metabolites of ginsenosides as novel BCRP inhibitors. Biochem Biophys Res Commun 2006, 345:|308-|3|4.

I 18. Wang $X$, Ling CO: Progress of the study on effective integredients from Chinese herbal medicine in anti-tumor metastasis. Zhonghua Wai Ke Za Zhi 2002, 40:606-608.

I 19. Kikuchi Y, Sasa H, Kita T, Hirata J, Tode T, Nagata I: Inhibition of human ovarian cancer cell proliferation in vitro by ginsenoside Rh2 and adjuvant effects to cisplatin in vivo. Anticancer Drugs 1991, 2:63-67.

120. Jia WW, Bu X, Philips D, Yan H, Liu G, Chen X, Bush JA, Li G: Rh2, a compound extracted from ginseng, hypersensitizes multidrug-resistant tumor cells to chemotherapy. Can J Physiol Pharmacol 2004, 82:431-437.

12I. Dong A, Ye M, Guo H, Zheng J, Guo D: Microbial transformation of ginsenoside RbI by Rhizopus stolonifer and Curvularia lunata. Biotechnol Lett 2003, 25:339-344.

122. Chi H, Ji GE: Transformation of ginsenosides Rb I and Re from Panax ginseng by food microorganisms. Biotechnol Lett 2005, 27:765-77I.

123. Chen MW, Ni L, Zhao XG, Niu XY: The inhibition of 20(R)-ginsenoside $\mathrm{Rg} 3$ on the expressions of angiogenesis factors proteins in human lung adenocarcinoma cell line A549 and HUVEC304 cell. Zhongguo Zhongyao Zazhi 2005, 30:357-360.

124. Yue PY, Wong DY, Wu PK, Leung PY, Mak NK, Yeung HW, Liu L, Cai ZW, jiang ZH, Fan TP, Wong RN: The angiosuppressive effects of 20(R)-ginsenoside Rg3. Biochem Pharmacol 2006, 72:437-445.

125. Huang YC, Chen CT, Chen SC, Lai PH, Liang HC, Chang Y, Yu LC, Sung HW: A natural compound (ginsenoside $\mathbf{R e}$ ) isolated from Panax ginseng as a novel angiogenic agent for tissue regeneration. Pharm Res 2005, 22:636-646. 
126. Liang HC, Chen CT, Chang Y, Huang YC, Chen SC, Sung HW: Loading of a novel angiogenic agent, ginsenoside $\mathrm{Rg} I$ in an acellular biological tissue for tissue regeneration. Tissue Eng 2005, I I:835-846.

127. Yue PY, Wong DY, Ha WY, Fung MC, Mak NK, Yeung HW, Leung HW, Chan K, Liu L, Fan TP, Wong RN: Elucidation of the mechanisms underlying the angiogenic effects of ginsenoside $\mathbf{R g}(\mathrm{I})$ in vivo and in vitro. Angiogenesis 2005, 8:205-216.

128. Morisaki N, Watanabe S, Tezuka M, Zenibayashi M, Shiina R, Koyama $\mathrm{N}$, Kanzaki T, Saito $\mathrm{Y}$ : Mechanism of angiogenic effects of saponin from ginseng Radix rubra in human umbilical vein endothelial cells. Br J Pharmacol | 995, I| 5: | |88-| | 93.

129. Fan TP, Yeh JC, Leung KW, Yue PY, Wong RN: Angiogenesis: from plants to blood vessels. Trends Pharmacol Sci 2006, 27:297-309.

130. Sengupta S, Toh SA, Sellers LA, Skepper JN, Koolwijk P, Leung HW, Yeung HW, Wong RN, Sasisekharan R, Fan TP: Modulating angiogenesis: the yin and the yang in ginseng. Circulation 2004, I 1 0:1219-1225.

13I. Cui JF: Identification and quantification of ginsenosides in various commercial ginseng preparations. EurJ Pharmacol Sci 1995, 3:77-85.

132. Ma YC, Luo M, Mally L, Doucet M: Distribution and proportion of major ginsenosides and quality control of ginseng products. Chi J Med Chem 1996, 6: I I-2I.

133. Ma ZC, Gao Y, Wang J, Zhang XM, Wang SQ: Proteomic analysis effects of ginsenoside Rg I on human umbilical vein endothelial cells stimulated by tumor necrosis factor-alpha. Life Sci 2006, 79: $175-181$.

134. Braga VM, Machesky LM, Hall A, Hotchin NA: The small GTPase Rho and Rac are required for the establishment of cadherindependent cell-cell contacts. J Cell Biol I997, I37:| 42 I- |43I.

135. Fukata M, Nakagawa M, Kuroda S, Kaibuchi K: Commentary Cell adhesion amd Rho small GTPase. J Cell Sci 1999, I I 2:449|-4500.

136. Nishiyama T, Sasaki T, Takaishi K, Kato M, Yaku H, Araki K, Matsuura $Y$, Takai $Y$ : Rac $\mathbf{2} \mathrm{I}$ is involved in insulin-induced memebrane ruffling and rho $\mathrm{P} 2 \mathrm{I}$ is involved in hepatocyte growth factorand 12-0-tetradecanoylphorbol-13-acetate (TPA)-induced membrane ruffling in KB cells. Mol Cell Biol 1994, 14:2447-2456.

137. Ridley AJ, Hall A: The small GTP-binding protein rho regulates the assembly of focal adhesions and actin stress fibers in response to growth factors. Cell 1992, 70:389-399.

138. Takaishi K, Sasaki T, Kato M, Yamochi W, Kuroda S, Nakamura T, Takeichi M, Takai Y: Involvement of Rho p2I samll GTP-binding protein and its regulator in the HGF-induced cell motility. Oncogene 1994, 9:273-279.

139. Schmitz AAP, Govek EE, Bottner B, Aelst LV: Rho GTPases: signaling, migration and invasion. Exp Cell Res 2000, 26I:I-12.

140. Kaibuchi K, Kuroda S, Amano M: Regukation of the cytoskeleton and cell adhesion by the Rho family GTPases in mammalian cells. Annu Rev Biochem 1999, 68:459-486.

14I. Kaibuchi K, Kuroda S, Fukata M, Nakagawa M: Regulation of cadherin-mediated cell-cell adhesion by the Rho family GTPases. Curr Opin Cell Biol I999, I I:591-596.

142. Braga V: Epithelial cell shape: cadherins and small GTPases. Exp Cell Res 2000, 26 I:83-90.

143. Abe K, Rossman KL, Liu B, Ritola KD, Chiang D, Campbell SL, Burridge $K$, Der C): Vav2 is an activator of Cdc42, Racl and RhoA. J Biol Chem 2000, 275: I0141-10149.

144. Bustelo XR: Regulatory and signaling properties of the Vav family. Mol Cell Biol 2000, 20:146 I- 1477.

145. Crespo P, Schuebel KE, Ostrom AA, Gutkind JS, Bustelo XR: Phosphototyrosine-dependent activation of Rac-I GDP/GTP exchange by the vav proto-oncogene product. Nature 1997, 385:169-172.

146. Liu BP, Burridge K: Vav2 activates racl, Cdc42 and RhoA downstream from growth factor receptor but not $\beta I$ integrins. Mol Cell Biol 2000, 20:7160-7169.

147. Aelst LV, Schorey CD: Rho GTPases and signaling networks. Genes Dev 1997, I I:2295-2322.

148. Noren NK, Liu BP, Burridge K, Kreft B: PI 20 catenin regulates the actin cytoskeleton via Rho family GTPases. J Cell Biol 2000, 150:567-579.

149. Kuroda S, Fukata M, Nakagawa M, Fujii K, Nakamura T, Ookubo T, Izawa I, Nagase T: Role of IQGAPI, a target of small GTPases
Cdc42 and Racl, in regulation of E-cadherin-mediated cellcell adhesion. Science 1998, 28I:832-835.

150. Kuroda S, Fukata M, Nakagawa M, Kaibuchi K: Cdc42, Racl and their effector IQGAPI as molecular switches for cadherinmediated cell-cell adhesion. Biochem Biophys Res Commun 1999, 262: $1-6$.

I5I. Fukata M, Kuroda S, Fujii K, Nakamurat T, Shoji I, Matsuura Y, Okawa K, Iwamatsu A, Kikuchi A, Kaibuchi K: Regulation of cross-linking of actin filament by IQGAPI a target for Cdc42. I Biol Chem 1997, 272:29579-29583.

152. Tashiro K, Sephel GC, Weeks BSM, Martin GR, Kleinman HK, Yamada $Y$ : A synthetic peptide containing the IKVAV sequence from the $A$ chain of laminin mediates cell attachment, migration and neurite outgrowth. J Biol Chem 1989, 264:16174-16182.

153. Kleinman HK, Weeks BS, Schnaper HW, Kibbey MC, Yamamura K, Grant DS: The laminins: a family of basement membrane glycoproteins important in cell differentiation and tumor metastases. Vitam Horm 1993, 47:161-186.

154. Grant DS, Tashiro K, Segui RB, Yamada Y, Martin GR, Kleinman HK: Two different laminin domains mediate the differentiation of human endothelial cells into capillary-like structure in vitro. Cell 1989, 58:933-943.

155. Malinda KM, Nomizu M, Chung M, Delgado M, Kiuratomi Y, Yamada $Y$, Kleinman HK: Identification of laminin $\alpha I$ and $\beta I$ chain peptides active for endothelial cell adhesion, tube formation and aortic sprouting. FASEB J 1999, 13:53-62.

156. Gonzales M, Weksler B, Tsuruta D, Goldman RD, Yoon KJ, Hopkinson SB, Flitney FW, Jones JCR: Structure and function of a vimentin-associated matrix adhesion in endothelial cells. Mol Biol Cell 2000, I 2:85-100.

157. Carmeliet P: Angiogenesis in life, disease and medicine. Nature 2005, 438:932-926.

158. Folkman J: Fundamental concepts of the angiogenic process. Curr Mol Med 2003, 3:643-65I.

159. Hoeben A, Landuyt B, Highley MS, Wildiers H, Van Oosterom AT, De Bruijn EA: Vascular endothelial growth factor and angiogenesis. Pharmacol Rev 2004, 56:549-580.

160. Rosano GM, Cornoldi A, Fini M: Effects of androgens on the cardiovascular system. J Endocrinol Invest 2005, 28(3 Suppl):32-38.

161. Critchley HO: Endometrial morphology and progestogens. Ernst Schering Res Found Workshop 2005, 52:55-88.

162. Liu PY, Death AK, Handelsman DJ: Androgens and cardiovascular disease. Endocr Rev 2003, 24:3 I3-340.

163. Stier CT Jr, Chander PN, Rocha R: Aldosterone as a mediator in cardiovascular injury. Cardiol Rev 2002, 10:97-107.

164. Yang S, Zhang L: Glucocorticoids and vascular reactivity. Curr Vasc Pharmacol 2004, 2: I- 12

165. White RE: Estrogen and vascular function. Vascul Pharmacol 2002, 38:73-80

166. Mendelsohn ME: Nongenomic, ER-mediated activation of endothelial nitric oxide synthase: how does it work? What does it mean? Circ Res 2000, 87:956-960.

167. Mendelsohn ME, Karas RH: The protective effects of estrogen on the cardiovascular system. N Engl J Med 1999, 340: $180|-| 8 \mid 1$.

168. Nathan L, Pervin S, Singh R, Rosenfeld M, Chaudhuri G: Estradiol inhibits leukocyte adhesion and transendothelial migration in rabbits in vivo: possible mechanisms for gender differences in atherosclerosis. Circ Res 1999, 85:377-385.

169. Haynes MP, Sinha D, Russell KS, Collinge M, Fulton D, Morales-Ruiz $M$, Sessa WC, Bender JR: Membrane estrogen receptor engagement activates endothelial nitric oxide synthase via the PI3kinase-Akt pathway in human endothelial cells. Circ Res 2000, 87:677-682.

170. Hisamoto K, Ohmichi M, Kurachi H, Hayakawa J, Kanda Y, Nishio $Y$, Adachi K, Tasaka K, Miyoshi E, Fujiwara N, Taniguchi N, Murata Y: Estrogen induces the Akt-dependent activation of endothelial nitric-oxide synthase in vascular endothelial cells. J Biol Chem 200I, 276:3459-3467.

171. Bae EA, Shin JE, Kim DH: Metabolism of ginsenoside Re by human intestinal microflora and its estrogenic effect. Biol Pharm Bull 2005, 28:1903-1908.

172. Cho J, Park W, Lee S, Ahn W, Lee Y: Ginsenoside-RbI from Panax ginseng C.A. Meyer activates estrogen receptor-alpha 
and -beta, independent of ligand binding. J Clin Endocrinol Metab 2004, 89:3510-3515.

173. Lee Y, Jin Y, Lim W, Ji S, Choi S, Jang S, Lee S: ginsenoside-Rh I, a component of ginseng saponin, activates estrogen receptor in human breast carcinoma MCF-7 cells. J Steroid Biochem Mol Biol 2003, 84:463-468.

174. Chan RY, Chen WF, Dong A, Guo D, Wong MS: Estrogen-like activity of ginsenoside Rg I derived from Panax notoginseng. J Clin Endocrinol Metab 2002, 87:369I-3695.

175. Tata JR: Signalling through nuclear receptors. Nat Rev Mol Cell Biol 2002, 3:702-710.

176. Rochette-Egly C: Nuclear receptors: integration of multiple signalling pathways through phosphorylation. Cell Signal 2003, I 5:355-366.

177. Lee YJ, Chung E, Lee KY, Lee YH, Huh B, Lee SK: Ginsenoside-Rg I, one of the major active molecules from Panax ginseng, is a functional ligand of glucocorticoid receptor. Mol Cell Endocrinol 1997, I33:135-140.

178. Dancey JE: Molecular targeting: PI3 kinase pathway. An Oncol 2004, I 5(suppl 4):233-239.

179. Leung KW, Cheng YK, Mak NK, Chan KK, Fan TP, Wong RW: Signaling pathway of ginsenoside-Rg I leading to nitric oxide production in endothelial cells. FEBS Lett 2006, 580:32II-32I6.

180. Leung KW, Pon YL, Wong RN, Wong AS: Ginsenoside-Rg I induces vascular endothelial growth factor expression through glucocorticoid receptor-related phosphatidylinositol 3-kinase/Akt and beta-catenin/TCF-dependent pathway in human endothelial cells. J Biol Chem 2006, 28 I:36280-36288.

18I. Furukawa T, Bai CX, Kaihara A, Ozaki E, Kawano T, Nakaya Y, Awais M, Sato M, Umezawa Y, Kurokawa J: Ginsenoside Re, a Main Phytosterol of Panax Ginseng, Activates Cardiac Potassium Channels via a Non-Genomic Pathway of Sex Hormones. Mol Pharmacol 2006, 70:1916-1924.

Publish with Bio Med Central and every scientist can read your work free of charge

"BioMed Central will be the most significant development for disseminating the results of biomedical research in our lifetime. "

Sir Paul Nurse, Cancer Research UK

Your research papers will be:

- available free of charge to the entire biomedical community

- peer reviewed and published immediately upon acceptance

- cited in PubMed and archived on PubMed Central

- yours - you keep the copyright 